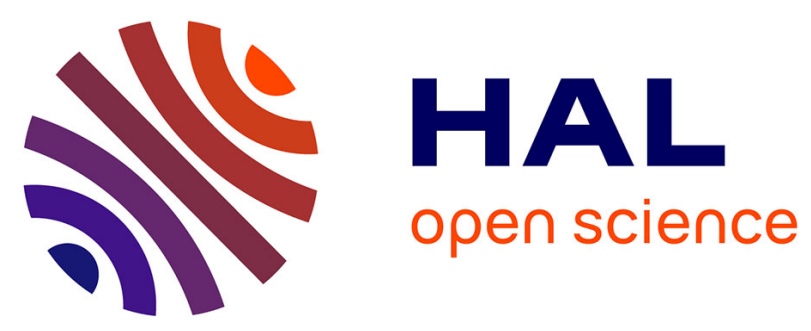

\title{
On the study of $\operatorname{Th}(\mathrm{IV})$-humic acid interactions by competition sorption studies with silica and determination of global interaction constants
} Pascal E. Reiller, V. Moulin, F. Casanova, Christian Dautel

\section{- To cite this version:}

Pascal E. Reiller, V. Moulin, F. Casanova, Christian Dautel. On the study of Th(IV)-humic acid interactions by competition sorption studies with silica and determination of global interaction constants. Radiochimica Acta, 2003, 91 (9), pp.513-524. 10.1524/ract.91.9.513.20000 . cea-00288418

\section{HAL Id: cea-00288418 https://hal-cea.archives-ouvertes.fr/cea-00288418}

Submitted on 18 Aug 2008

HAL is a multi-disciplinary open access archive for the deposit and dissemination of scientific research documents, whether they are published or not. The documents may come from teaching and research institutions in France or abroad, or from public or private research centers.
L'archive ouverte pluridisciplinaire $\mathbf{H A L}$, est destinée au dépôt et à la diffusion de documents scientifiques de niveau recherche, publiés ou non, émanant des établissements d'enseignement et de recherche français ou étrangers, des laboratoires publics ou privés. 


\title{
On the study of Th(IV)-humic acid interactions by competition sorption studies with silica and determination of global interaction constants
}

\author{
By Pascal Reiller ${ }^{1, *}$, Valérie Moulin ${ }^{2}$, Florence Casanova ${ }^{1}$ and Christian Dautel ${ }^{1}$ \\ ${ }^{1}$ Commissariat à l'Énergie Atomique, CEA Saclay, Nuclear Energy Division/DPC/SECR/Laboratoire de Spéciation des Radionucléides \\ et des Molécules, F-91191 Gif-sur-Yvette CEDEX, France \\ ${ }^{2}$ Commissariat à l'Énergie Atomique, CEA Saclay, Nuclear Energy Division/DDIN, F-91191 Gif-sur-Yvette CEDEX, France
}

(Received October 25, 2001; accepted in final form February 18, 2003)

\begin{abstract}
Humic substances / Humic acids / Silica / Colloids / Retention / Thorium / Tetravalent actinides / Complexation
\end{abstract}

Summary. The influence of humic acids (HA) on the retention of thorium (IV) onto the surface of silica colloids is investigated. Thorium is considered as an analogue of tetravalent actinides $(\mathrm{U}, \mathrm{Np}, \mathrm{Pu})$, except for the fact that it has no $f$ electrons. Silica $\left(\mathrm{SiO}_{2}\right)$ is chosen as a model surface because it is a component of many minerals and because of its weak HA sorption properties. Retention experiments are performed by batch procedure at constant ionic strength $\left(I=0.1 \mathrm{M} \mathrm{NaClO}_{4}\right)$, at various $\mathrm{pH}$ (2 to 9$)$ and HA concentrations $(1-100 \mathrm{mg} / \mathrm{L})$. The sorption of Th(IV) onto colloidal amorphous silica is characterised using a surface complexation model. The ternary system (i.e. HA-Th-Silica) clearly shows the influence of $\mathrm{HA}$ on $\mathrm{Th}(\mathrm{IV})$ retention. This can lead to a strong reduction of the amount of Th(IV) sorbed onto silica in the presence of HA compared to silica colloids without $\mathrm{HA}$, due to a predominant part of thorium present in solution as humic complexes. In a $\mathrm{pH}$ range where no organic coating onto silica occurs, there is a competitive reaction between Th(IV) sorption onto the silica surface and onto HA reactive functional groups. In this case, Schubert's method is applied to obtain a global interaction constant for the Th(IV)-HA system. The large interaction constant values indicate a strong affinity of HA for Th(IV).

\section{Introduction}

The importance of colloidal matter on the facilitated transport of heavy metals in natural systems is now well accepted [1-4]. It is of particular importance to determine the influence of humic substances (HS, humic and fulvic acids, HA/FA), constituting nearly half of the dissolved organic matter present in groundwater [5-7], on the migration of radionuclides, particularly the actinide elements.

The complexation and sorption behaviour of mono, di or trivalent metal ions are now well documented. However, data on tetravalent cations, e.g. Th, $\mathrm{Zr}, \mathrm{Hf}$, are relatively scarce due to experimental difficulties met with their use: i.e. low solubility of the oxides $[8,9]$ and sorption on vessel

\footnotetext{
*Author for correspondence (E-mail: pascal.reiller@cea.fr).
}

walls [10]. In deep groundwater, the redox potential $\left(E_{\mathrm{h}}\right)$ is expected to be negative inducing reducing conditions, so redox sensitive actinide elements are expected to be predominantly in their tetravalent form, i.e., U(IV), $\mathrm{Np}(\mathrm{IV}), \mathrm{Pu}(\mathrm{IV})$. Knowledge of the tetravalent element behaviour in natural groundwater in the presence of humic substances is thus of a great importance. Moreover, $\mathrm{Np}(\mathrm{V}), \mathrm{Pu}(\mathrm{VI})$ and $\mathrm{Pu}(\mathrm{V})$ are reduced to $\mathrm{Np}(\mathrm{IV})$ and $\mathrm{Pu}(\mathrm{IV})$ by $\mathrm{HS}$ [11-15].

Thorium is regarded as an analogue for the other tetravalent actinides [16]. Investigations of Th(IV) sorption onto mineral surfaces have been reported in the literature [10,17-23]. These studies indicate that the cationmineral interaction is strong and the retention edge of $\mathrm{Th}(\mathrm{IV})$ on $\mathrm{SiO}_{2}, \mathrm{TiO}_{2}$, goethite, hematite or alumina is observed near $\mathrm{pH} 2-3$. The silica-Th(IV) system has been previously studied by Östhols et al. [10], using a diffuse double layer surface complexation model (SCM) [24], and by Zaki and Kolta [25]. Literature data on the sorption of tetravalent elements on surfaces are scarce compared to $d$ transition elements, mostly because of the experimental constraints related to these elements. As noted in [10], referring to [26], it is difficult to find any vessel material that would allow studies at $\mathrm{pH} \geq 3$, since tetravalent elements have strong affinities for any surfaces. Clear experimental evidences for a strong sorption of thorium onto silicate mineral surfaces in a large $\mathrm{pH}$ range are mentioned in $[17,27,28]$. In natural systems, tetravalent cations, including Th(IV), are associated with particulate or colloidal matter present in groundwater and their chemistries are not controlled by the precipitation of a single mineral phase [27-30].

The strong interaction of thorium with humic substances is known [31-34]. Data concerning the complexation of Th(IV) with humic substances have been compiled by Nash and Choppin [35] and revised by Choppin and Allard [36]. The authors described the increasing complexation strength of HA for Th(IV) with increasing $\mathrm{pH}$ using an operational equation as a function of HA ionisation $[37,38]$. The $\log { }^{\mathrm{HA}} \beta$ value in [35] ranges from 10.6 at $\mathrm{pH} 3.5$ to 13.2 at $\mathrm{pH} 5$ (with ${ }^{\mathrm{HA}} \beta$ given in $\mathrm{L} / \mathrm{eq}$ ) referring to Baes and Mesmer hydrolysis data sets [39] and acetate complexation of Th(IV) [40]. Recently, Murphy et al. [41] deter- 
mined the complexation constant for the Th(IV)-HA system at $\mathrm{pH} 3.5\left(\log { }^{\mathrm{HA}} \beta=7.5\right.$ with ${ }^{\mathrm{HA}} \beta$ given in $\left.\mathrm{L} / \mathrm{eq}\right)$ referring to Grenthe et al. hydrolysis data sets $[42,43]$. Unfortunately, the data were obtained in a $\mathrm{pH}$ range which is irrelevant of natural media $(3.5 \leq \mathrm{pH} \leq 5)$ and caution must be taken for their application to conditions of natural waters $(6 \leq \mathrm{pH} \leq 9)$. Zuyi and Huanxin determined the constants for soil $\mathrm{HA}$ and $\mathrm{FA}$ at $\mathrm{pH}=6$ [44], the $\log { }^{\mathrm{HA}} \beta$ values were comparable with [35]. Davis et al. [45] studied the Th(IV)FA system between pH 5.3 and $6.5\left(5.6 \leq \log { }^{\mathrm{FA}} \beta \leq 6.2\right.$ with ${ }^{\mathrm{FA}} \beta$ given in $\mathrm{L} / \mathrm{g}$ ) and did not correct their data from hydrolysis.

Denecke et al. [46] and Schild and Marquardt [47] showed that under acidic conditions the Th-HA bonding occurs through carboxylate functions. However, the increasing complexing strength of $\mathrm{HA}$ with $\mathrm{pH}$ cannot be explained solely by complexation with HA carboxylate functions. This phenomenon has been interpreted to indicate that either mixed complexes form $[48,49]$ or an activation of other HA (phenolic) sites occurs [50]. Hence, it appears that, except for Davis et al. [45] whose experiments have been conducted up to $\mathrm{pH} 6.5$ with FA, no studies on the complexation of Th(IV) by HA have been performed under natural groundwater conditions where competing reactions exist, in particular hydrolysis. The question emerges to what extent the extrapolation of data obtained under acidic conditions can be extrapolated to higher $\mathrm{pH}$, where competing ligands are present and where ternary complexes (or mixed complexes) may formed.

The presence of a competing ligand such as HA can strongly influence the retention of heavy metals onto mineral phases [51-56]. Although mechanisms involved in the sorption of HS onto mineral surfaces $[57,58]$ are not fully understood, many general trends are well known. Zachara et al. [53] have shown that when HA and the mineral are pre-equilibrated, cobalt (II) retention is more pronounced when the amount of HA is less than needed to saturate the mineral surface. When the concentration of HA surpasses the saturation of the mineral surface, LabonneWall et al. [54], Takahashi et al. [55] and Reiller et al. [56] reported that metal cation retention decreases with increasing $\mathrm{pH}$. These effects depend upon the relative proportions of HA and mineral phase sorption sites.

The objective of this paper is to study the influence of HA on the sorption of a tetravalent actinide Th(IV) onto a mineral surface. The competition between HA and this surface is used to study the complexation of Th(IV) by HA, as pointed out by Vuceta and Morgan [59]. A silica colloidal suspension has been chosen as a model mineral surface because silica is one of the major components of colloidal matter in natural waters [60]. This study is focused on the system of a silica colloidal suspension, HA and thorium (IV), characterising it as a function of $\mathrm{pH}$ (2-8.5) and HA concentration $(1-100 \mathrm{mg} / \mathrm{L})$. The different equilibria involved in the binary $\left(\mathrm{Th}-\mathrm{SiO}_{2}\right)$ system are described using a surface complexation model, SCM (without an electrostatic term). These results, combined with the experimental data for the $\mathrm{Th}(\mathrm{IV})-\mathrm{HA}-\mathrm{SiO}_{2}$ ternary system, are used to determine apparent global interaction constants for Th-HA.

\section{Experimental}

\subsection{Materials}

The silica suspension is obtained from AEA Harwell [61]. The surface properties is taken from Brady [62]:

$$
\equiv \mathrm{SOH} \rightleftarrows \mathrm{SO}^{-}+\mathrm{H}^{+} \quad \mathrm{p} K_{\mathrm{a} 2}=6.54 ;
$$

the point of zero charge $\mathrm{pH}_{\mathrm{pzc}}$ is 2-3 [63]; $C_{\mathrm{e}}$, the proton exchange capacity, PEC, is taken to be $0.3 \mathrm{meq} / \mathrm{g}$.

Purified Aldrich HA is used in a protonated form. Characteristics of this HA are described by Kim et al. [64]. The PEC for HA-Aldrich was determined in [64] by potentiometric titration $\left(W_{\mathrm{HA}}=5.4 \times 10^{-3} \mathrm{eq} / \mathrm{g}\right)$ and by the $\mathrm{Ba}(\mathrm{OH})_{2}$ adsorption and Ca-acetate methods $(4.8 \times$ $10^{-3} \mathrm{eq} / \mathrm{g}$ by $\left(\mathrm{CH}_{3} \mathrm{COO}\right)_{2} \mathrm{Ca}$ for carboxylic groups and $2.26 \times 10^{-3} \mathrm{eq} / \mathrm{g}$ with $\mathrm{Ba}(\mathrm{OH})_{2}$ for phenolic groups). The apparent acidity constant (determined as the $\mathrm{pH}$ at midequivalence) is $\mathrm{p} K_{\mathrm{a}}^{\mathrm{HA}}=4.52$.

The initial thorium solution $\left({ }^{228} \mathrm{Th}\right.$ in $\left.2 \mathrm{M} \mathrm{HNO}_{3}\right)$ is obtained from Amersham. This solution is diluted in order to obtain a $1.09 \times 10^{-9} \mathrm{M}$ stock solution in $0.9 \mathrm{M} \mathrm{NaClO}_{4}$ and $0.2 \mathrm{M} \mathrm{HNO}_{3}$. All other chemicals are reagent grade and Millipore water is used.

\subsection{Experimental}

The sorption experiments are conducted in batch procedure at room temperature in polycarbonate vials sealed with screw caps. The silica suspension is prepared by diluting a stock solution with the background electrolyte to the desired concentration. Aliquots of $\mathrm{HA}$ are added and the $\mathrm{pH}$ is adjusted to the desired value with a TACUSSEL $\mathrm{pH}$ metre (PHM 220 MeterLab) equipped with a combined TACUSSEL electrode (Radiometer type XC 161, modified $\mathrm{NaClO}_{4}$ $\left.0.1 \mathrm{M}, \mathrm{NaCl} 10^{-2} \mathrm{M}\right)$, using $\mathrm{HClO}_{4}(0.1 \mathrm{M})$ or freshly prepared $\mathrm{NaOH}(0.1 \mathrm{M})$. The combined electrode was calibrated against commercial $\mathrm{pH}$ buffers $(\mathrm{pH}=4,7,9)$. The ionic strength is kept constant $\left(\mathrm{NaClO}_{4} 0.1 \mathrm{M}\right)$ through all of the experiments. HA concentration is measured spectrophotometrically at $254 \mathrm{~nm}$ (Shimadzu UV-2100), neglecting chromism effects [65]. The suspension is shaken for 24 hours to allow equilibration of the adsorbent. Enough $\mathrm{Th}(\mathrm{IV})$ solution is added to obtain a final concentration of $1.15 \times 10^{-12} \mathrm{M}$ and the $\mathrm{pH}$ is readjusted. The solution is shaken again for 24 hours. Three $1 \mathrm{~mL}$ aliquots of the suspension are sampled for thorium activity measurement $\left(A_{1}\right)$, in order to get rid of Th(IV) adsorption on vial walls as described by Cromières et al. [23]. Colloids are separated from the liquid phase by ultracentrifugation $(90 \mathrm{~min}, 50000 \mathrm{rpm})$, the $\mathrm{pH}$ of the supernatant is measured and then three $1 \mathrm{~mL}$ aliquots are sampled from the supernatant for thorium activity measurement $\left(A_{2}\right)$.

The activities of ${ }^{228} \mathrm{Th}$ are measured by liquid scintillation counting. Sampled aliquots are added to $4 \mathrm{~mL}$ of liquid scintillator (Ultima Gold AB). The activity measurements are performed after one month in order to attain the secular equilibrium of ${ }^{228} \mathrm{Th}$ with its daughters. In the initial solution thorium activity $\left(A_{0}\right)$ is determined by direct addition into the liquid scintillator (Packard TRI-CARB 2700 TR).

The percent amount of Th(IV) sorbed, $R(\%)$, is calculated from the activities of the suspension $\left(A_{1}\right)$ and of the 
supernatant $\left(A_{2}\right)$ according to the following equation:

$$
R(\%)=\frac{A_{1}-A_{2}}{A_{1}} \times 100 .
$$

The distribution coefficient, $K_{\mathrm{d}}$, is given by:

$$
\begin{aligned}
K_{\mathrm{d}} & =\frac{C_{\mathrm{Th}_{\text {sorbed }}}}{[\mathrm{Th}]_{\text {solution }}}=\left(\frac{A_{1}}{A_{2}}-1\right)=\frac{V(\mathrm{ml})}{m_{\mathrm{SiO}_{2}}(\mathrm{~g})} \\
& =\frac{R}{100-R} \times \frac{10^{6}}{C_{\mathrm{SiO}_{2}}(\mathrm{mg} / \mathrm{L})},
\end{aligned}
$$

where $V$ is the volume of the suspension, $m_{\mathrm{SiO}_{2}}$ is the mass of added silica.

\subsection{Thorium chemistry}

Th(IV) speciation diagrams for the conditions of these experiments are depicted in Fig. 1. Because of the low Th concentration, only the monomers induced by the hydrolysis need to be taken into account. Th(IV) hydrolysis constants are those determined by Baes and Mesmer [39] (Fig. 1a) and by Ekberg et al. [66] (Fig. 1b), as well as those determined by Grenthe et al. [42,43] (Fig. 1c) in order to take into account for $\mathrm{CO}_{3}{ }^{2-}$ complexation. Note that the constant for $\mathrm{Th}(\mathrm{OH})_{4}(\mathrm{aq})$ neutral complex in these three references remains two to four orders of magnitude higher than the upper limit of this constant estimated by Ryan and Rai [8] ${ }^{l}$. The cumulative constants of Th(IV), corrected for $0.1 \mathrm{M}$ ionic strength using the Specific Interaction Theory (SIT), are reported in Table 1 ( $\varepsilon_{\mathrm{Th}(\mathrm{IV})}$ were taken as equal to $\varepsilon_{\mathrm{U}(\mathrm{IV})}$ in Grenthe et al. [67]). The total carbonate concentration in our experimental closed system has been estimated by Labonne [68] and Cromières [69] to be $5 \times 10^{-5} \mathrm{M}$. The carbonato complexes, $\mathrm{ThCO}_{3}(\mathrm{OH})_{3}{ }^{-}$and $\mathrm{Th}\left(\mathrm{CO}_{3}\right)_{5}{ }^{6-}$, suggested by different authors $[43,70-72]$ have been taken into account. The pentacarbonatothorate(IV) limiting complex is of minor importance under our conditions. Tetravalent actinides are suspected to form silicate complexes but have not been yet quantified [73].

\footnotetext{
${ }^{1} \log * \beta_{4} \leq-19.4$
}
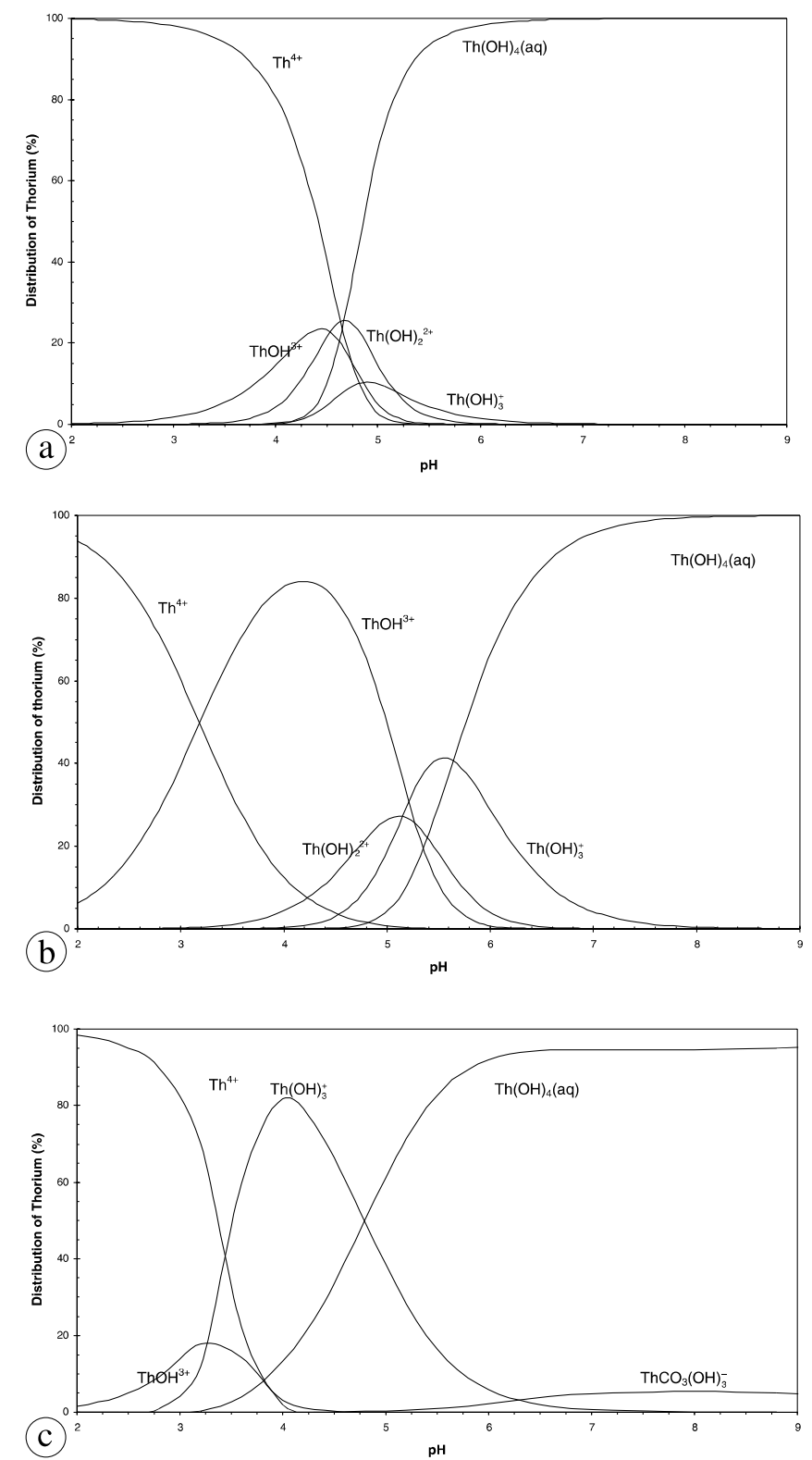

Fig. 1. Speciation diagram for thorium. $I=0.1 \mathrm{M}\left(\mathrm{NaClO}_{4}\right),[\mathrm{Th}]=$ $10^{-12} \mathrm{M},\left[\mathrm{CO}_{3}\right]_{t}=5 \times 10^{-5} \mathrm{M}$, referring to: (a) [42,43], (b) [39], (c) [66].
Table 1. Complexation cumulative

\begin{tabular}{|c|c|c|c|}
\hline Equilibrium & $\begin{array}{c}\log * \beta_{i} \\
{[39]} \\
I=0.1 \mathrm{M}\end{array}$ & $\begin{array}{c}\log { }^{*} \beta_{i} \\
{[42,43]} \\
I=0.1 \mathrm{M}\end{array}$ & $\begin{array}{c}\log { }^{*} \beta_{i} \\
{[66]} \\
I=0.1 \mathrm{M}\end{array}$ \\
\hline $\begin{array}{l}\mathrm{Th}^{4+}+\mathrm{H}_{2} \mathrm{O} \rightleftarrows \mathrm{Th}(\mathrm{OH})^{3+}+\mathrm{H}^{+} \\
\mathrm{Th}^{4+}+2 \mathrm{H}_{2} \mathrm{O} \rightleftarrows \mathrm{Th}(\mathrm{OH})_{2}{ }^{2+}+2 \mathrm{H}^{+} \\
\mathrm{Th}^{4+}+3 \mathrm{H}_{2} \mathrm{O} \rightleftarrows \mathrm{Th}(\mathrm{OH})_{3}{ }^{+}+3 \mathrm{H}^{+} \\
\mathrm{Th}^{4+}+4 \mathrm{H}_{2} \mathrm{O} \rightleftarrows \mathrm{Th}(\mathrm{OH})_{4}+4 \mathrm{H}^{+} \\
\mathrm{Th}^{4+}+\mathrm{CO}+3 \mathrm{H}_{2} \mathrm{O} \rightleftarrows \mathrm{ThCO}_{3}(\mathrm{OH})_{3}{ }^{-}+3 \mathrm{H}^{+}\end{array}$ & $\begin{array}{c}-3.9 \\
-8.0 \\
-13.0 \\
-17.4 \\
-\end{array}$ & $\begin{array}{l}-3.8 \\
- \\
-10.4 \\
-15.2 \\
-2.2\end{array}$ & $\begin{array}{l}-2.7 \\
-7.7 \\
-12.7 \\
-18.3 \\
-\end{array}$ \\
\hline & $\begin{array}{c}\log { }^{*} \beta_{\mathrm{i}} \\
{[67]} \\
I=0.1 \mathrm{M}\end{array}$ & & \\
\hline $\begin{array}{l}\mathrm{H}_{4} \mathrm{SiO}_{4} \rightleftarrows \mathrm{H}_{3} \mathrm{SiO}_{4}^{-}+\mathrm{H}^{+} \\
\mathrm{H}_{4} \mathrm{SiO}_{4} \rightleftarrows \mathrm{H}_{2} \mathrm{SiO}_{4}{ }^{2-}+2 \mathrm{H}^{+} \\
2 \mathrm{H}_{4} \mathrm{SiO}_{4} \rightleftarrows \mathrm{H}_{5} \mathrm{Si}_{2} \mathrm{O}_{7}^{-}+\mathrm{H}^{+} \\
2 \mathrm{H}_{4} \mathrm{SiO}_{4} \rightleftarrows \mathrm{H}_{4} \mathrm{Si}_{2} \mathrm{O}_{7}{ }^{2-}+2 \mathrm{H}^{+}\end{array}$ & $\begin{array}{r}-9.6 \\
-22.6 \\
-7.9 \\
-18.4\end{array}$ & & \\
\hline
\end{tabular}
constants of Th(IV), corrected for $0.1 \mathrm{M}$ ionic strength using SIT method. 
The experimental points of Th sorption experiment onto $\mathrm{SiO}_{2}$ are fit using FITEQL 3.2 [74]. The criteria of the FITEQL code "SOS/DF" defined as the ratio of the sum of least squares on the degrees of freedom ( $7 \%$ relative error on $\mathrm{Th}_{\mathrm{ads}}$, and $2 \%$ relative error in $\mathrm{pH}$ ) is used to determine the quality of the fit.

\section{Binary system}

Thorium retention by various minerals has been studied using SCM [19, 20, 22, 23, 43]. Laflamme et al. [19], Hunter et al. [20] and Cromières et al. [23] obtained comparable results for iron oxides. The authors determined surface complexation constants referring to the Baes and Mesmer [39] hydrolysis data sets.

The retention can be modelled following the assumption via the following reactions scheme and constants:

$$
\begin{aligned}
& \overline{\equiv \mathrm{SOH}} \rightleftarrows \overline{\equiv \mathrm{SO}^{-}}+\mathrm{H}^{+} \quad K=\frac{\overline{\left[\equiv \mathrm{SO}^{-}\right]\left[\mathrm{H}^{+}\right]}}{[\overline{\equiv \mathrm{SOH}}]} \\
& \overline{\equiv \mathrm{SOH}}+\mathrm{Th}^{4+}+(n-1) \mathrm{H}_{2} \mathrm{O} \rightleftarrows \overline{\equiv \mathrm{SOTh}(\mathrm{OH})_{n-1}{ }^{4-n}} \\
& +n \mathrm{H}^{+}, \\
& K_{n}=\frac{\overline{\left[\equiv \mathrm{SOTh}(\mathrm{OH})_{n-1}{ }^{4-n}\right]\left[\mathrm{H}^{+}\right]^{n}}}{[\equiv \mathrm{SOH}]\left[\mathrm{Th}^{4+}\right]} .
\end{aligned}
$$

\section{Ternary system}

The formation of a complex between thorium and HA, to which the mass action law is applied, can be represented as follows:

$$
{ }^{\mathrm{HA}} \beta=\frac{[\text { ThHA }]}{[\mathrm{Th}][\equiv \mathrm{HA}]},
$$

where $\equiv \mathrm{HA}$ can be considered as a site, ${ }^{\mathrm{HA}} \beta$ is an apparent global interaction constant where a formal stoichiometry is not necessary. The humic site concentration $[\equiv \mathrm{HA}]$ is calculated as:

$$
[\equiv \mathrm{HA}]=W_{\mathrm{HA}}(\mathrm{eq} / \mathrm{g}) \times C_{\mathrm{HA}}(\mathrm{g} / \mathrm{L}) .
$$

Determination of ${ }^{\mathrm{HA}} \beta$ is straightforward assuming that there is no interaction between the mineral surface and HA. This is the case for silica at $\mathrm{pH}>6.5$, as shown on Fig. 2, as already shown in the case of silica surface $[54,55,75]$, or on clay [76]. Furthermore, contrary to oxalic acids, humic acids do not appear to increase feldspar dissolution rate [77].

Combining Eqs. (3), (4) and (5), the portion of sorbed Th(IV) is obtained:

$$
\begin{aligned}
P & =\frac{\left[\mathrm{Th}_{\text {fixed }}\right]}{\left[\mathrm{Th}_{\text {total }}\right]} \\
= & \frac{\sum_{n} K_{n}[\equiv \mathrm{SOH}]\left[\mathrm{Th}^{4+}\right]\left[\mathrm{H}^{+}\right]^{-(n+1)}}{\left\{\begin{array}{c}
\alpha_{\mathrm{Th}}\left[\mathrm{Th}^{4+}\right]+{ }^{\mathrm{HA}} \beta\left[\mathrm{Th}^{4+}\right][\equiv \mathrm{HA}] \\
+\sum_{n} K_{n}[\equiv \mathrm{SOH}]\left[\mathrm{Th}^{4+}\right]\left[\mathrm{H}^{+}\right]^{-(n+1)}
\end{array}\right\}},
\end{aligned}
$$

where $\alpha_{\mathrm{Th}}$ is the Ringböm coefficient concerning inorganic complexation:

$$
\alpha_{\mathrm{Th}}=1+\sum_{i} \frac{{ }^{*} \beta_{i}}{\left[\mathrm{H}^{+}\right]^{i}}+\sum_{j} \beta_{j}\left[\mathrm{CO}_{3}^{2-}\right]^{j} \ldots
$$

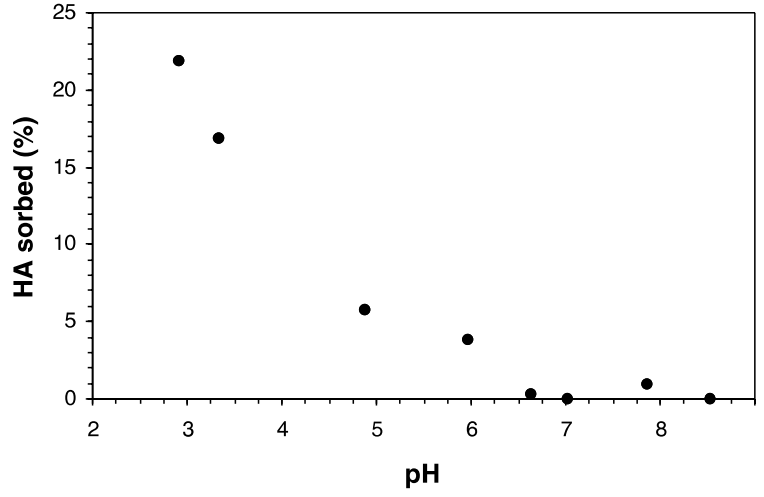

Fig. 2. Sorption of HA onto silica colloids, $[\mathrm{HA}]=0.01 \mathrm{~g} / \mathrm{L}, I=$ $0.1 \mathrm{M}\left(\mathrm{NaClO}_{4}\right),\left[\mathrm{SiO}_{2}\right]_{i}=0.25 \mathrm{~g} / \mathrm{L}$.

When the system can be considered as purely competitive $(\mathrm{pH} \geq 6.5)$, the following equation can be written:

$$
{ }^{\mathrm{HA}} \beta=\frac{\left((1-P) \sum_{n} K_{n}[\equiv \mathrm{SOH}]\left[\mathrm{H}^{+}\right]^{-(n+1)}\right)-P \alpha_{\mathrm{Th}}}{P[\equiv \mathrm{HA}]} .
$$

As the Th(IV) concentration is at trace level, the following equation is valid:

$$
{ }^{\mathrm{HA}} \beta=\frac{\left(\frac{(1-P) C_{\mathrm{e}}}{\alpha_{\mathrm{SiOH}}} \sum_{n} K_{n}\left[\mathrm{H}^{+}\right]^{-(n+1)}\right)-P \alpha_{\mathrm{Th}}}{P[\equiv \mathrm{HA}]},
$$

where $\alpha_{\mathrm{SiOH}} \cong\left(1+10^{-6.54+\mathrm{pH}}\right)$ neglecting the proportion of Th surface complexes.

The ${ }^{\mathrm{HA}} \beta$ can thus be estimated at a $\mathrm{pH}$ value where no HA sorption onto a mineral is assumed.

Competitive reaction systems are easily studied using the Schubert's method [78]. The following expressions are used to analyse the data from the ternary system to ultimately determine ${ }^{\mathrm{HA}} \beta$ of the Th(IV)-HA system.

When Th(IV) is sorbed onto silica, the distribution coefficient is written:

$$
\begin{aligned}
K_{\mathrm{d}}^{\circ} & =\frac{\left[\mathrm{Th}_{\mathrm{sorb}}\right]}{\left[\mathrm{Th}_{\mathrm{aq}}\right]}=\frac{\sum_{n}\left[\equiv \mathrm{SOTh}(\mathrm{OH})_{n}{ }^{(4-n)+}\right]}{\left[\mathrm{Th}_{\mathrm{aq}}\right]} \\
= & \frac{\sum_{n} K_{n} \frac{[\equiv \mathrm{SOH}]}{\left[\mathrm{H}^{+}\right]^{n}}}{\left(1+\sum_{n} \frac{{ }^{*} \beta_{n}}{\left[\mathrm{H}^{+}\right]^{n}}\right)} \\
K_{\mathrm{d}}^{\circ} & =\frac{\sum_{n} K_{n} \frac{[\equiv \mathrm{SOH}]}{\left[\mathrm{H}^{+}\right]^{n}}}{\alpha_{\mathrm{Th}}} .
\end{aligned}
$$

When the competition between silica and HA takes place, the distribution coefficient is:

$$
\begin{aligned}
K_{\mathrm{d}} & =\frac{\left[\mathrm{Th}_{\mathrm{sorb}}\right]}{\left[\mathrm{Th}_{\mathrm{aq}}\right]}=\frac{\sum_{n}\left[\equiv \mathrm{SOTh}(\mathrm{OH})_{n}{ }^{(4-n)+}\right]}{\left[\mathrm{Th}_{\mathrm{aq}}\right]} \\
= & \frac{\sum_{n} K_{n} \frac{[\equiv \mathrm{SOH}]}{\left[\mathrm{H}^{+}\right]^{n}}}{\left(1+\sum_{n} \frac{{ }^{*} \beta_{n}}{\left[\mathrm{H}^{+}\right]^{n}}+{ }^{\mathrm{HA}} \beta[\equiv \mathrm{HA}]\right)} .
\end{aligned}
$$


Thus, one can write:

$$
K_{\mathrm{d}}=\frac{\sum_{n} K_{n} \frac{[\equiv \mathrm{SOH}]}{\left[\mathrm{H}^{+}\right]^{n}}}{\alpha_{\mathrm{Th}}+{ }^{\mathrm{HA}} \beta[\equiv \mathrm{HA}]} .
$$

The resulting Schubert equation is:

$$
\begin{aligned}
\log \left[\left(\frac{K_{\mathrm{d}}^{\circ}}{K_{\mathrm{d}}}-1\right) \times \alpha_{\mathrm{Th}}\right] & =\log B \\
& =n \log [\equiv \mathrm{HA}]+\log { }^{\mathrm{HA}} \beta,
\end{aligned}
$$

where $n$ is the number of ligand reacting per metal, $\alpha_{\mathrm{Th}}$ is the Ringböm coefficient for hydrolysis of Th(IV), [ $\equiv \mathrm{HA}]$ is the concentration of HA sites given in eq/L (defined as the product of the HA concentration in $\mathrm{g} / \mathrm{L}$ and the proton exchange capacity $\left.W_{\mathrm{HA}}\right)$, and $\log { }^{\mathrm{HA}} \beta$ is the apparent interaction constant of the Th-HA system (with ${ }^{\mathrm{HA}} \beta$ given in $\mathrm{L} / \mathrm{eq}$ ). Under the $\mathrm{pH}$ conditions studied here, all carboxylic sites are ionised. Silicate species are not considered to interact with $\mathrm{HA}$, as only weak interactions are mentioned in the literature $[79,80]$, and no interactions with silanol groups occurs for $\mathrm{pH}>6.5$.

\section{Results and discussion}

\subsection{Sorption of thorium onto silica}

The results obtained for the retention of Th(IV) onto silica colloids versus $\mathrm{pH}$ in the range 2-9 are shown on Fig. 3 $\left([\mathrm{Th}]_{\mathrm{ads}}=f(\mathrm{pH})\right)$. Error bars are the mean experimental uncertainty $(\cong 5 \%)$. As expected from former studies [19-23], the sorption edge is around $\mathrm{pH} 2-3$. The sorption remains relatively constant up to $\mathrm{pH} \mathrm{8-9.} \mathrm{Using} \mathrm{the} \mathrm{amorphous} \mathrm{sil-}$ ica solubility constant $\left(\log K_{\mathrm{s}}=-2.71\right)$ and orthosilicic acid hydrolysis constant recommended in Grenthe et al. [67] (Table 1), the experimental data can be modelled in the $\mathrm{pH}$ range $2-7$, where the dissolution of silica is not extensive.

The main difference between our results and those of Östhols [10], is that the sorption of Th(IV) onto silica does not result in maximal sorption at a $\mathrm{pH}$ range 2-7.5. A progressive sorption edge is observed, similar to other oxides [19-21, 23]. Th(IV) is fixed onto silica in neutral $\mathrm{pH}$ media, as is it the case in natural medium $[27,28]$.

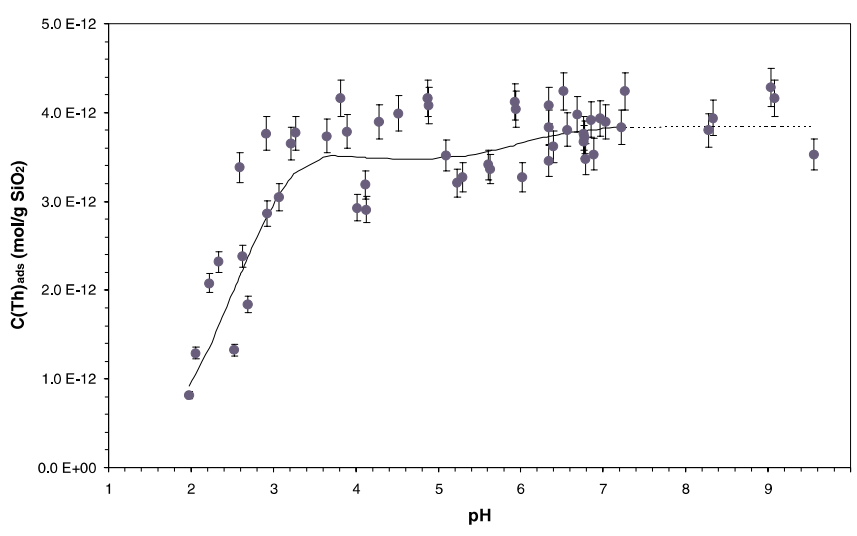

Fig. 3. $[\mathrm{Th}]_{\mathrm{ads}}\left(\mathrm{mol} / \mathrm{g} \mathrm{SiO}_{2}\right)$ versus $\mathrm{pH}$ onto silica colloids. $I=0.1 \mathrm{M}$ $\left(\mathrm{NaClO}_{4}\right),\left[\mathrm{SiO}_{2}\right]_{i}=0.25 \mathrm{~g} / \mathrm{L}[\mathrm{Th}]=1.5 \times 10^{-12} \mathrm{M}$.
From his sorption study of $\mathrm{Th}(\mathrm{IV})$ onto silica at $\mathrm{pH} \leq 3.5$, and subsequent SCM fitting, Östhols [10] postulates a bidentate nature of Th(IV) sorbed species on colloidal silica. An EXAFS study of this system confirmed the results in the acidic $\mathrm{pH}$ range [81]. The surface coverage in the sorption study is four orders of magnitude higher than in our conditions $\left(8.35 \times 10^{-8}\right.$ to $9.9 \times 10^{-6} \mathrm{~mol} \mathrm{Th} / \mathrm{g} \mathrm{SiO}_{2}$ in [10]; $4 \times 10^{-12} \mathrm{~mol} \mathrm{Th} / \mathrm{g} \mathrm{SiO}_{2}$ in this study). In the EXAFS study, the thorium concentration was high $\left(10^{-4}-10^{-2} \mathrm{M}\right)$ and is not relevant to any natural situation, where $\mathrm{Th}(\mathrm{IV})$ is expected to be present at trace levels.

Using SCM many authors demonstrated the existence of two types of surface sorption sites: "strong" and "weak" sites [82]. Our experiments are performed at low Th concentrations so we assume that only strong binding sites are concerned here. The interaction constants obtained are only relevant to the "strong" binding sites of silica, due to trace metal concentration used (i.e. $10^{-12} \mathrm{M}$ ).

Monodentate surface complexes seem to be a justified approximation to describe our results. Under similar conditions, monodentate surface complexes have been used to successfully describe the sorption of Eu(III) onto hematite $\left(\alpha-\mathrm{Fe}_{2} \mathrm{O}_{3}\right)$ [83] or $\mathrm{Np}(\mathrm{V})$ onto hydrargilite $\left(\mathrm{Al}(\mathrm{OH})_{3}\right)$ [84]. As pointed out by Davis and Kent [85], in SCM the complexation exceeds the electrostatic contribution for strong adsorbing ions, including multivalent actinides. Furthermore, in our study, the very low coverage of surface silica by $\mathrm{Th}(\mathrm{IV})$ lowers the possible lateral coulombic interactions [86]. Hence, for our peculiar study, the use of a nonelectrostatic SCM is justified.

The surface complexation constants describing the sorption of Th(IV) onto silica surface ( $\equiv \mathrm{SOH}$ groups) obtained from fits to the data are presented in Table 2. The fitting exercises are performed using hydrolysis constants of Baes and Mesmer [39], Grenthe et al. [42, 43] and Ekberg et al. [66]. Hydroxo surface complexes $\left(\equiv \operatorname{SOTh}(\mathrm{OH})_{n-1}{ }^{(4-n)+}\right.$ with $n$ varying from 1 to 5 ) are needed to fully describe the sorption of thorium on silica colloids under our experimental conditions. The fit does not converge using a bidentate surface complex alone for Th(IV) sorption in acidic solution and the hydrolysis data recommended by Baes and Mesmer [39]. The use of the hydrolysis constants of Grenthe et al. [42,43] and a bidentate surface complex yields a poor fit (SOS/DF $>100$, data not shown). Fig. 3 compares experimental data to the model curve obtained using the surface complexation constants in Table 2 .

Our fits are not in agreement with the assumption made in [10] that $\mathrm{Th}(\mathrm{IV})$ sorption onto silica is limited to a $\mathrm{pH}$ range between 2 and 7. However, Östhols studied Th(IV) sorption onto Aerosil OX 200 silica (pyrogenic) in acidic media. The pyrogenic silica can be compared to vitreous silica used by Rydberg and Rydberg [26] and to the substrate used by James and Healy [18]. Using his SCM results in acidic media ( $\mathrm{pH} \leq 3.25)$, Östhols [10] successfully fit the results of [26] and [18] with a bidentate complex. These results, however, cannot be applied to the distribution of Th(IV) in groundwater rich in silica [27,28]. One may also not directly compare data obtained using a pyrogenic silica substrate with a sol-gel silica [87]. It is known that precipitated silica (sol-gel) surface charge, BET surface density and total exchangeable protons are greater than 
Table 2. Parameters for the surface complexation study of Th onto silica.
Equilibrium

\begin{tabular}{|c|c|c|c|c|}
\hline $\begin{array}{l}\equiv \mathrm{SOH} \rightleftarrows \equiv \mathrm{SO}^{-}+\mathrm{H}^{+} \\
\text {Surface site concentration }\end{array}$ & $\begin{array}{c}-6.54 \\
0.3 \mathrm{meq} / \mathrm{g}\end{array}$ & & & \\
\hline Hydrolysis data set & \multicolumn{2}{|c|}{$[42,43]$} & [39] & {$[66]$} \\
\hline$\equiv \mathrm{SOH}+\mathrm{Th}^{4+} \rightleftarrows \equiv \mathrm{SOTh}^{3+}+\mathrm{H}^{+}$ & $1.6 \pm 0.1$ & $1.6 \pm 0.1$ & $1.6 \pm 0.1$ & $1.7 \pm 0.1$ \\
\hline $2 \equiv \mathrm{SOH}+\mathrm{Th}^{4+} \rightleftarrows(\equiv \mathrm{SO})_{2} \mathrm{Th}^{2+}+2 \mathrm{H}^{+}$ & - & $2.3 \pm 0.5$ & - & - \\
\hline$\equiv \mathrm{SOH}+\mathrm{Th}^{4+}+\mathrm{H}_{2} \mathrm{O} \rightleftarrows \equiv \mathrm{SOThOH}^{2+}+2 \mathrm{H}^{+}$ & & & & $1.55 \pm 0.3$ \\
\hline$\equiv \mathrm{SOH}+\mathrm{Th}^{4+}+2 \mathrm{H}_{2} \mathrm{O} \rightleftarrows \equiv \mathrm{SOTh}(\mathrm{OH})_{2}{ }^{+}+3 \mathrm{H}^{+}$ & $-5.1 \pm 0.3$ & - & - & - \\
\hline$\equiv \mathrm{SOH}+\mathrm{Th}^{4+}+3 \mathrm{H}_{2} \mathrm{O} \rightleftarrows \equiv \mathrm{SOTh}(\mathrm{OH})_{3}+4 \mathrm{H}^{+}$ & - & $-9.9 \pm 0.3$ & $-12.0 \pm 0.4$ & - \\
\hline$\equiv \mathrm{SOH}+\mathrm{Th}^{4+}+4 \mathrm{H}_{2} \mathrm{O} \rightleftarrows \equiv \mathrm{SOTh}(\mathrm{OH})_{4}{ }^{-}+5 \mathrm{H}^{+}$ & $-15.9 \pm 0.3$ & $-16.3 \pm 0.6$ & $-18.2 \pm 0.5$ & $-19.1 \pm 0.4$ \\
\hline $\mathrm{SOS} / \mathrm{DF}$ & 5.2 & 5.3 & 5.3 & 5.8 \\
\hline
\end{tabular}

for pyrogenic silica [87]. Furthermore, the hydroxylation of the pyrogenic silica sample used by Östhols [10], was performed in neutral to strongly acidic media. This treatment undoubtedly minimises the formation of polysilicates induced by the dissolution of the surface ([10], p. 1237). In our experiments, the silica suspension is stored in slightly alkaline medium, similar to the experiments reported by Yates and Healy [87]. Under these conditions, the total hydroxylation of the surface, considering the hydration kinetics of heat-treated silica [88], and the formation of polysilicates are then possible. These polynuclear complexes of orthosilic acid are suspected to complex thorium in solution [73], and could be responsible of the enhancement of the retention onto silica surface compared to the vitreous silica.

\subsection{Effect of the presence of HA on the sorption of thorium onto silica}

The effect of HA on the sorption of Th(IV) onto silica with varying HA concentration $(1,10,50$ and $100 \mathrm{mg} / \mathrm{L})$ is presented in Fig. 4. As expected, retention of Th(IV) onto silica decreases with increasing HA concentration. As in the case of $\mathrm{Th}(\mathrm{IV})$ sorption onto hematite [56] and $\mathrm{Zr}(\mathrm{IV})$ onto kaolinite and silica [55], the presence of HA has a strong impact on the sorption even in slightly basic media. This is likely due to the formation of soluble thorium organic complexes.

As silicate ions are not known to be associated with HA $[79,80]$, the interaction constant of Th(IV)-HA complex can be estimated using the surface complexation data determined at a $\mathrm{pH}$ value where no sorption of HA onto silica occurs, i.e., $\mathrm{pH}=7-8$. Under these conditions, an apparent global interaction constant, referring to [39], is estimated

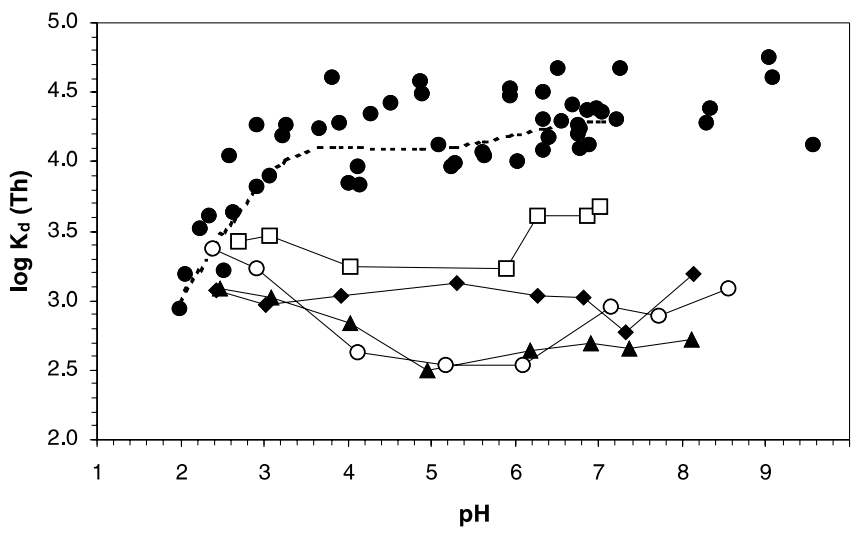

Fig. 4. Influence of HA on the sorption of Th(IV) onto silica colloids vs. pH: $[\mathrm{Th}]=1.15 \times 10^{-12} \mathrm{M},\left[\mathrm{SiO}_{2}\right]=0.25 \mathrm{~g} / \mathrm{L}, I=0.1 \mathrm{M}$ $\left(\mathrm{NaClO}_{4}\right) ; \bullet[\mathrm{HA}]=0, \square[\mathrm{HA}]=10^{-3} \mathrm{~g} / \mathrm{L}, \bullet[\mathrm{HA}]=10^{-2} \mathrm{~g} / \mathrm{L}$, $\Delta[\mathrm{HA}]=5 \times 10^{-2} \mathrm{~g} / \mathrm{L}, \circ[\mathrm{HA}]=0.1 \mathrm{~g} / \mathrm{L}$.

(Table 3). These values are compared with the $\log { }^{\mathrm{HA}} \beta\left(\mathrm{Th}^{4+}\right)$ calculated from the following equation [36]:

$$
\log { }^{\mathrm{HA}} \beta\left(\mathrm{Th}^{4+}\right)=7.1^{\mathrm{HA}} \alpha+9.2,
$$

where ${ }^{\mathrm{HA}} \alpha$ is the ionisation coefficient of Lake Bradford HA ( ${ }^{\mathrm{HA}} \beta=0.9$ for $\mathrm{pH}=7$, and ${ }^{\mathrm{HA}} \alpha=0.99$ for $\mathrm{pH}=8$ ) [37].

The $\log { }^{\mathrm{HA}} \beta$ estimated clearly show that the Th(IV)-HA complexes are strong, which is in agreement with [36]. However, our values are larger than those that can be extrapolated from [36] for the same hydrolysis constant data set. The different HA used within these two works may not totally explain this discrepancy (Aldrich versus Lake Bradford) as Nash and Choppin determined very close value of $\log { }^{\mathrm{HA}} \beta$ for these two different humic acids at $\mathrm{pH} \approx 4[35]$.

Table 3. Global interaction constants for the Th-HA system calculated from the constants in Table 2 referring to [39].

\begin{tabular}{|c|c|c|c|c|c|c|c|c|c|c|c|c|c|}
\hline & $\mathrm{pH}$ & $P(\%)$ & $\log { }^{\mathrm{HA}} \beta$ & $\mathrm{pH}$ & $P(\%)$ & $\log { }^{\mathrm{HA}} \beta$ & $\mathrm{pH}$ & $P(\%)$ & $\log { }^{\mathrm{HA}} \beta$ & $\mathrm{pH}$ & $P(\%)$ & $\log { }^{\mathrm{HA}} \beta$ & $\log _{\mathrm{BM}} \overline{\overline{\mathrm{HA}} \beta}$ \\
\hline$[\mathrm{HA}](\mathrm{mg} / \mathrm{L})$ & & $100 \mathrm{mg} / \mathrm{L}$ & & & $50 \mathrm{mg} / \mathrm{L}$ & & & $10 \mathrm{mg} / \mathrm{L}$ & & & $1 \mathrm{mg} / \mathrm{L}$ & & \\
\hline $\mathrm{pH} \approx 8$ & 8.1 & 27.8 & 21.0 & 8.1 & 11.5 & 21.7 & 8.1 & 27.8 & 22.0 & - & - & - & $21.6 \pm 1.3$ \\
\hline $\mathrm{pH} \approx 7.5$ & - & - & - & - & - & - & - & - & - & 7.6 & 54.5 & 20.2 & - \\
\hline $\mathrm{pH} \approx 7$ & 6.8 & 21.1 & 15.8 & 6.9 & 10.9 & 16.9 & 6.8 & 21.1 & 16.8 & 6.9 & 50.4 & 17.6 & $16.8 \pm 1.2$ \\
\hline
\end{tabular}




\subsection{Competition between silica and $\mathrm{HA}$ at constant pHusing}

Fig. 5 presents the results of complexing behaviour of HA towards Th(IV) using silica colloids as a competing agent at constant $\mathrm{pH}$ values $6.7 \pm 0.2,7.2 \pm 0.1$ and $7.9 \pm 0.1$. The concentration range chosen for this experiment covers the widest range which HA are encountered in natural media. It can be seen this competitive system behave like the ternary system Th, $\alpha-\mathrm{Fe}_{2} \mathrm{O}_{3}$ and HA [56], where the sorption minimum is around $\mathrm{pH}=7$.

These results are plotted according to Eq. (13) in Fig. 6, using $[42,43]$ data sets for hydrolysis and carbonate complexation. The following linear relations satisfactorily represent the points:

$$
\begin{gathered}
\log B_{\mathrm{pH}=6.7}=(1.3 \pm 0.2) \log [\equiv \mathrm{HA}]+(18.2 \pm 1.0) ; \\
r^{2}=0.9612 ; \\
\log B_{\mathrm{pH}=7.2}=(1.1 \pm 0.3) \log [\equiv \mathrm{HA}]+(19.4 \pm 1.1) ; \\
r^{2}=0.9387 ; \\
\log B_{\mathrm{pH}=7.9}=(1.0 \pm 0.1) \log [\equiv \mathrm{HA}]+(21.3 \pm 0.6) ; \\
r^{2}=0.9757 ;
\end{gathered}
$$

using a $95 \%$ confidence interval.

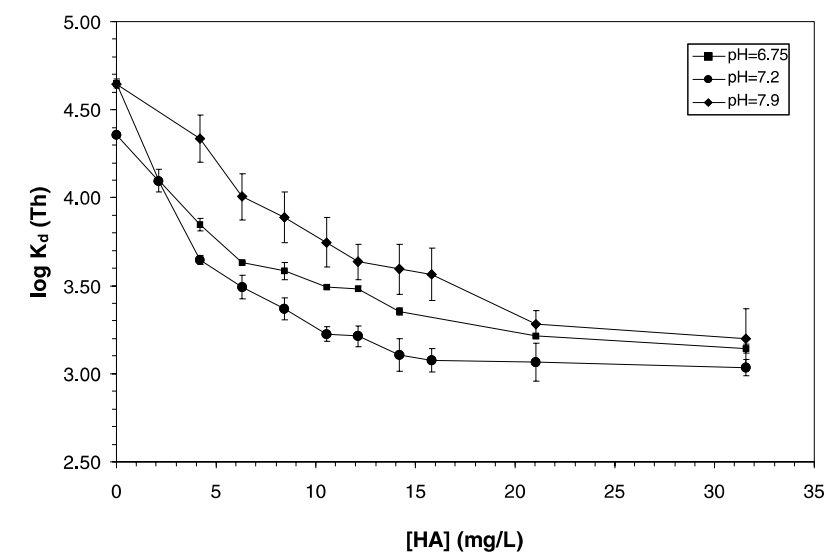

Fig. 5. Plot of the distribution coefficient $K_{\mathrm{d}}$ for Th(IV) in the competing system silica colloids-HA-Th at constant $\mathrm{pH}$. $\left[\mathrm{SiO}_{2}\right]_{i}=0.25 \mathrm{~g} / \mathrm{L}$, $[\mathrm{Th}]=10^{-12} \mathrm{M},\left[\mathrm{NaClO}_{4}\right]=0.1 \mathrm{M}: \square \mathrm{pH}=6.7 \pm 0.2 ; \bullet \mathrm{pH}=7.2 \pm$ $0.1 ; \diamond \mathrm{pH}=7.9 \pm 0.1$.

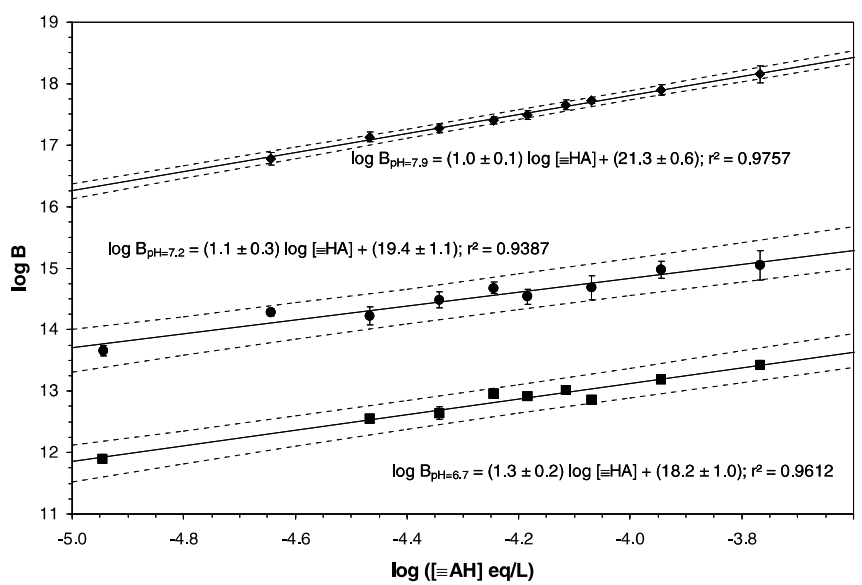

Fig. 6. Plot of Eq. (13) for Th(IV)-HA system, using silica colloids as competitor, referring to $[42,43] .\left[\mathrm{NaClO}_{4}\right]=0.1 \mathrm{M}: \mathbf{\mathrm { pH }}=6.7 \pm 0.2$; $\bullet \mathrm{pH}=7.2 \pm 0.1 ; \diamond \mathrm{pH}=7.9 \pm 0.1$.
The slope of the plots in Fig. 6 are near unity, indicating that $n$ is 1 at all $\mathrm{pH}$ values. The values obtained for $\log { }_{\mathrm{N}}^{\mathrm{HA}} \beta\left(\mathrm{Th}^{4+}\right.$ ) (the indice $N$ refers to the hydrolysis constants data set used, i.e., GL for Grenthe et al. [42,43], BM for Baes and Mesmer [39] and EK for Ekberg et al. [66]) from extrapolation of the plots to the $y$-axis intercept are summarised in Table 4.

The differences between the $\log { }_{\mathrm{N}}^{\mathrm{HA}} \beta\left(\mathrm{Th}^{4+}\right)$ values come from the differences in $\log \alpha_{\mathrm{Th}}$, since different Th hydrolysis constant data sets are used. In the $\mathrm{pH}$ range used in this study, $\mathrm{Th}(\mathrm{OH})_{4}(\mathrm{aq})$ is the dominant species. Hence Eq. (13) can be rewritten:

$$
\log \left(\frac{K_{\mathrm{d}}^{\circ}}{K_{\mathrm{d}}}-1\right)+\log \alpha_{\mathrm{Th}}=n \log [\equiv \mathrm{HA}]+\log _{\mathrm{N}}^{\mathrm{HA}} \beta .
$$

Using this equation, $\log { }_{\mathrm{N}}^{\mathrm{HA}} \beta$ can be calculated for any Th hydrolysis constant data sets, as for example those proposed in $[89,90]$.

These $\log { }_{\mathrm{N}}^{\mathrm{HA}} \beta$ results are comparable to the estimated values in the previous section and are about two to four orders of magnitude higher that those reported at $\mathrm{pH} \leq$ $5.5[35,36]$ and ten logarithmic units more than those determined at $\mathrm{pH}=3.5$ [41]. The different results obtained in this study, referring to the same Th(IV) inorganic complexation data set from Baes and Mesmer [39], are summarised on Fig. 7 , where the $\log { }_{\mathrm{N}}^{\mathrm{HA}} \beta$ values are compared

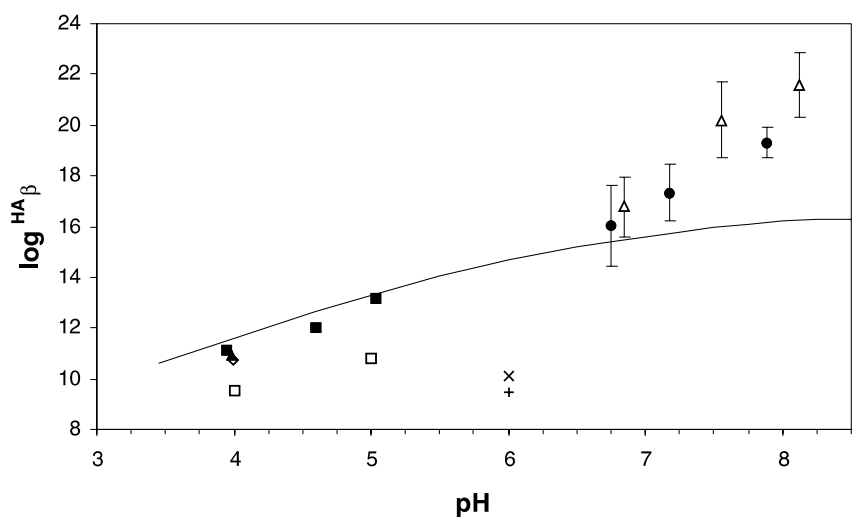

Fig. 7. Variation of the global stability constants $\log _{\mathrm{BM}}^{\mathrm{HA}} \beta$, referring to [39], for Th(IV) humic complexes as a function of $\mathrm{pH}$; plain line Eq. (14) proposed by [36]: - Lake sediment HA, $\diamond$ Soil HA, $\triangle$ Aldrich HA, $\square$ Aldrich FA from [35]; $\times$ Soil HA, + Soil FA from [44]; this study, $\bullet[\mathrm{HA}]$ isotherm (Table 4$), \triangle \mathrm{pH}$ isotherm (Table 3 ).

Table 4. Global interaction constants for the Th(IV)-HA system determined at pH 6.75, 7.2 and 7.9 (from Fig. 6) $-I=0.1 \mathrm{M} \mathrm{NaClO}_{4}$.

\begin{tabular}{llcc}
\hline $\begin{array}{l}\text { Hydrolysis } \\
\text { constants set }\end{array}$ & $\mathrm{pH}$ & $\begin{array}{c}\log { }^{\mathrm{HA}} \beta \\
\text { this work }\end{array}$ & $\begin{array}{c}\log { }^{\mathrm{HA}} \beta \text { from } \\
\text { Eq. (14) [36,37] }\end{array}$ \\
\hline$[39]$ & 6.75 & $16.2 \pm 1.0$ & 15.4 \\
& 7.2 & $17.3 \pm 1.1$ & 15.8 \\
& 7.9 & $19.3 \pm 0.6$ & 16.2 \\
\hline$[42,43]$ & 6.75 & $18.2 \pm 1.0$ & \\
& 7.2 & $19.4 \pm 1.1$ & \\
\hline$[66]$ & 7.9 & $21.3 \pm 0.6$ & \\
& 6.75 & $16.4 \pm 1.0$ & \\
& 7.2 & $17.5 \pm 1.1$ & \\
\hline
\end{tabular}


to the experimental values obtained in $[35,44]$. The plot of Eq. (14) proposed in [36] versus $\mathrm{pH}$ is also mentioned. It can be seen that the importance of humic complexation is higher than previously postulated extrapolating expression Eq. (14). The linear trend observed for Th(IV) is in agreement with observations made on other metals as noted by Hummel et al. [91]. Further studies are needed to ascertain this point.

Fig. 8 presents the percent of thorium in humic complexes plotted versus the concentration of $\mathrm{HA}(\mathrm{g} / \mathrm{L}$ and eq/L assuming $5.4 \times 10^{-3} \mathrm{eq} / \mathrm{g}$ ) at $\mathrm{pH} 7.2$ (Fig. 8a) and 7.9 (Fig. 8b) using $\log \underset{\mathrm{BM}}{\mathrm{HA}} \beta$ values. It can be seen that, if the humic complexation of $\mathrm{Th}(\mathrm{IV})$ is important at $\mathrm{pH} 7.2$ for $[\mathrm{HA}]=100 \mathrm{mg} / \mathrm{L}$, it is apparently unimportant for the same humic concentration at $\mathrm{pH} 7.9$ when $\log \underset{\mathrm{BM}}{\mathrm{HA}} \beta$ from [36] is used. These results are not in agreement with field observations (Table 2 in [92], and Table 1 in [93]) where thorium appears to be associated with humic substances as already discussed in [94]. Using the global interaction constants $\log \underset{\mathrm{BM}}{\mathrm{HA}} \beta$ determined in this study, referring to [39], humic complexation is still predominant down to $10^{-4} \mathrm{~g} / \mathrm{L}$
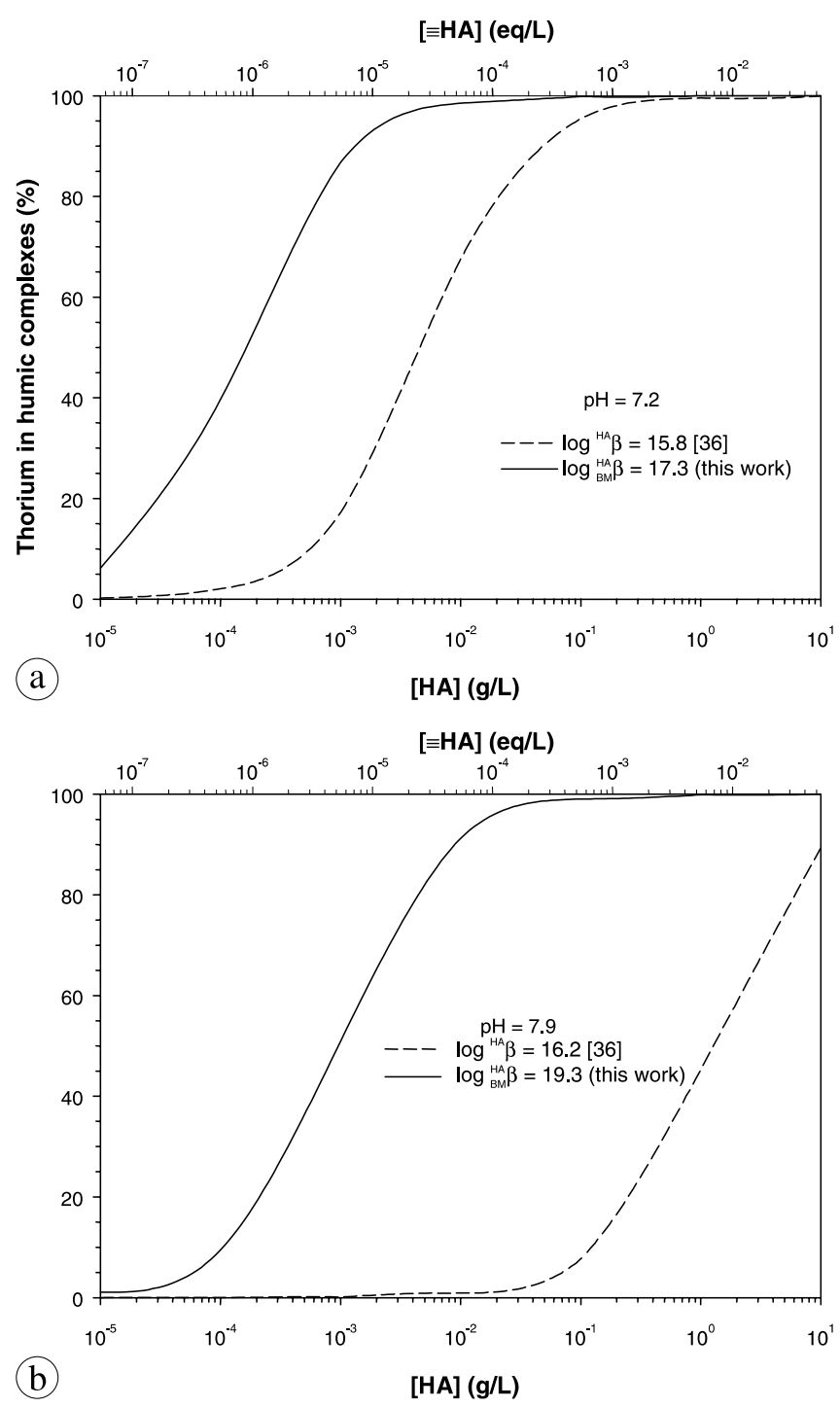

Fig. 8. Percent thorium in humic complexes as a function of HA concentration at fixed $\mathrm{pH}$, values are referring to [39]: (a) $\mathrm{pH}=7.2$, (b) $\mathrm{pH}=7.9$; plain line this work, dashed lines [36]. at $\mathrm{pH}=7.2$, and $10^{-3} \mathrm{~g} / \mathrm{L}$ at $\mathrm{pH}=7.9$. In the latter case, $\mathrm{Th}(\mathrm{IV})$ is quantitatively associated to $\mathrm{HA}$ at $0.1 \mathrm{~g} / \mathrm{L}$ which is in agreement with field observations [30,32,33,92,93] for the same conditions, even if the type of HA are not the same in both cases.

The increase in $\log { }^{\mathrm{HA}} \beta$ with $\mathrm{pH}$ raises the question of the type of bonding between Th(IV) and HA in natural media. The works of Denecke et al. [46] (EXAFS) and Schild and Marquardt [47] (XPS) clearly showed that the carboxylate functional groups are primarily responsible for an important role in the humic complexation of Th(IV) in acidic media. However, this would not be entirely the case for Th-HA bonding in neutral to slightly acidic media. The increase in $\log { }^{\mathrm{HA}} \beta$ with $\mathrm{pH}$ may indicate that mixed Th(IV)humate complexes form, similar to observations made for cobalt [49], uranium [49,95], cadmium, europium [48], americium and curium $[96,97]$. This could be related to the chemistry of Th(IV), i.e., formation of hydrolysed forms at high $\mathrm{pH}$, or to the role of phenolic functional groups in HA in metal binding as well as conformational changes in HA molecules with increasing $\mathrm{pH}[50,98]$.

\subsection{Consequences on thorium mobility}

\section{Extent of Th-HA complexation}

As discussed previously [94], the extent of tetravalent elements complexation by HA is still under debate $[41,56,91$, 99, 100]. To explore this, the extent of Th-HA complexation is calculated using our global interaction constant and data for natural groundwater reported in the literature. The first illustrative example is an argillaceous groundwater defined in [94] (Table 5), with a concentration of HA varying from $10^{-5} \mathrm{~g} / \mathrm{L}$ to $10 \mathrm{~g} / \mathrm{L}\left(W_{\mathrm{HA}}=5.4 \times 10^{-3} \mathrm{eq} / \mathrm{g}\right)$ and a total Th concentration of $10^{-10} \mathrm{M}$. Only the complexation data of $[42,43]$ were used to take into account for Th(IV) carbonate complexation.

Fig. 9 shows the percent Th(IV) present as humate complexes obtained at $\mathrm{pH} 7.2$ using $\log \mathrm{GL}_{\mathrm{GA}}^{\mathrm{HA}} \beta\left(\mathrm{Th}^{4+}\right)=19.4$ and at pH 7.9 with $\log { }_{\mathrm{GL}}^{\mathrm{HA}} \beta\left(\mathrm{Th}^{4+}\right)=21.3$, with or without considering the complexation of Th(IV) by carbonate ions (Fig. 9a and $9 \mathrm{~b}$ respectively). The percent $\mathrm{Th}(\mathrm{IV})$ fixed to humic acids calculated using $\log \underset{\mathrm{BM}}{\mathrm{HA}} \beta$ (Fig. 8), and $\log \underset{\mathrm{GL}}{\mathrm{HA}} \beta$, neglecting carbonate complexation (Fig. 9a), are the same since

Table 5. Composition of the argillaceous water considered in Reiller et al. [94].

\begin{tabular}{lc}
\hline$T\left({ }^{\circ} \mathrm{C}\right)$ & 16.9 \\
$E(\mathrm{mV})$ & -155 \\
Total inorganic carbon $(\mathrm{M})$ & $4.75 \times 10^{-3}$ \\
\hline $\mathrm{Na}(\mathrm{M})$ & $6.15 \times 10^{-2}$ \\
$\mathrm{~K}(\mathrm{M})$ & $7.20 \times 10^{-4}$ \\
$\mathrm{Ca}(\mathrm{M})$ & $4.70 \times 10^{-3}$ \\
$\mathrm{Mg}(\mathrm{M})$ & $7.70 \times 10^{-3}$ \\
$\mathrm{Fe}(\mathrm{M})$ & $4.00 \times 10^{-7}$ \\
$\mathrm{Al}(\mathrm{M})$ & $5.00 \times 10^{-8}$ \\
\hline Silicate $(\mathrm{M})$ & $1.80 \times 10^{-4}$ \\
$\mathrm{Cl}(\mathrm{M})$ & $4.28 \times 10^{-2}$ \\
Total Sulphur (M) & $9.50 \times 10^{-3}$ \\
\hline
\end{tabular}



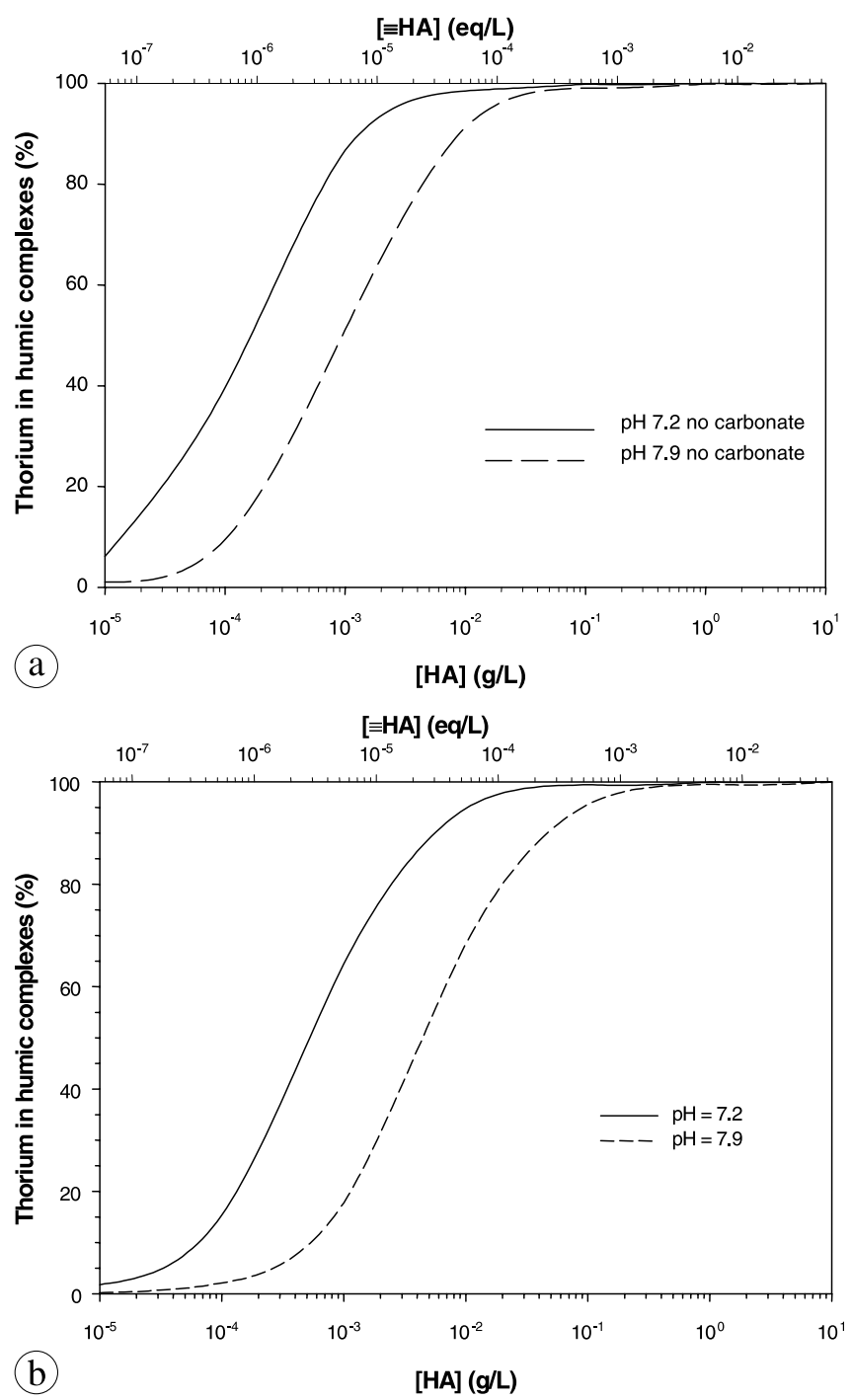

Fig. 9. Percent thorium in HA complexes as a function of HA concentration, $[\mathrm{Th}]=10^{-10} \mathrm{M}$ at $\mathrm{pH} 7.2$ and 7.9 , in clayey water (defined in Reiller et al. [94]), $\log { }_{\mathrm{GL}}^{\mathrm{HA}} \beta$ values (referring to $[42,43]$ constant set): (a) no competition with carbonate ions; (b) competition with carbonate ions.

inner coherent data base are used. Using our results in Fig. 9 obtained with our determined global interaction constants, humic complexation of thorium is more important than estimated from other data.

When the complexation of Th(IV) by carbonate ions is taken into account (Fig. 9b) in the clayey water, the association of Th(IV) with HA remains significant. Th(IV) humic complexes are predominant when $C_{\mathrm{HA}}$ is above $5 \times 10^{-4} \mathrm{~g} / \mathrm{L}$ at $\mathrm{pH}=7.2$ and $5 \times 10^{-3} \mathrm{~g} / \mathrm{L}$ at $\mathrm{pH}=7.9$. For $C_{\mathrm{HA}}=0.1 \mathrm{~g} / \mathrm{L}, \mathrm{Th}(\mathrm{IV})$ is quantitatively fixed to HA at $\mathrm{pH}=7.2$, and the percent Th bound to humic complexes is greater than $95 \%$ at $\mathrm{pH}=7.9$.

\section{Validation on independent data}

As a validation, calculations could be performed using PHREEQC [101] on independent data, with the composition of two Gorleben groundwaters (Germany, Gohy-573 and GoHy-2227 given in $[64,92,93,102])$ and with the MontTerri Opalinus clay extracts (Switzerland, [103]). In the case

of Gorleben groundwater, significant amount of Th(IV) is bound to HS. A weak influence of organic matter was evidenced in the case of Opalinus clay extracts.

In the case of Gorleben, $C_{\mathrm{HA}}$, in grams of carbon per liter, and $\mathrm{pH}$ are given in $[93,102](0.096 \mathrm{~g} \mathrm{C} / \mathrm{L}$, 56 wt. \% of carbon, $\mathrm{pH}=7.9$ for GoHy-573; $0.080 \mathrm{~g} \mathrm{C} / \mathrm{L}$, 56.6 wt. \% of carbon, $\mathrm{pH}=7.8$ for Gohy-2227), and $W_{\mathrm{HA}}$ are available in $[93,104]\left(4.91 \times 10^{-3} \mathrm{eq} / \mathrm{g}\right.$ for Gohy-2227; $5.38 \times 10^{-3} \mathrm{eq} / \mathrm{g}$ for GoHy-573). The global interaction constant used is $\log \underset{\mathrm{GL}}{\mathrm{HA}} \beta\left(\mathrm{Th}^{4+}\right)=21.3$ from our present study. The constants recommended by [67] are used for carbonate and silicate systems, and WATEQ4F data base for other auxiliary data (complexation of other metals). The thorium concentration in these groundwater was $1.6 \mu \mathrm{g} / \mathrm{L}$ in Gohy-2227 ([93] Table 1) and 3.7 $\mu \mathrm{g} / \mathrm{L}$ in Gohy-573 ([92] Table 2). The concentration of humic sites is thus calculated as:

$$
[\equiv \mathrm{HA}]=W_{\mathrm{HA}} \times \frac{C_{\mathrm{HA}}(\mathrm{mg} \mathrm{C} / \mathrm{L})}{\text { wt. } \% \text { carbon }} .
$$

Under these assumptions, $1.56 \mu \mathrm{g} \mathrm{Th} / \mathrm{L}$ is found to be bound to HA (Fig. 10) in the case of GoHy-2227 groundwater, which is in agreement with the experimental value $(1.51 \mu \mathrm{g} / \mathrm{L}$; Table 1 in [93]). In the case of Gohy-573 groundwater, $3.2 \mu \mathrm{g} / \mathrm{L}$ of thorium is complexed by HA, which is also in agreement with experimental data $(3.5 \mu \mathrm{g} / \mathrm{L}$; Table 2 in [92]).

In the case of the Opalinus clay, Glaus et al. [103] studied the influence of water extracted organic matter on the sorption of Th(IV) onto an ion exchange resin. The obtained $K_{\mathrm{d}}$ values evidenced a weak influence of organic matter on the sorption of Th(IV). For their experiments, six extracts were used: 3 extracts from Mont-Terri security gallery (MT) and 3 extracts from Benken borehole (BE), with the ionic compositions available in Table 3 in [103]. For these six extracts, the maximum possible fractions of HA were estimated to be $5 \%$ of the total organic carbon $\left(5.5-12 \times 10^{-3} \mathrm{~g} \mathrm{C} / \mathrm{L}\right)$ from the UV-Visible spectra. This allows us to estimate the humic site concentrations as:

$$
[\equiv \mathrm{HA}] \approx 0.05 \times[\mathrm{HA}](\mathrm{g} \mathrm{C} / \mathrm{L}) \times 5.4 \times 10^{-3}(\mathrm{eq} / \mathrm{g}) .
$$

As the $\mathrm{pH}$ of these extracts were in the range 8.2-8.4, the $\log { }_{\mathrm{GL}}^{\mathrm{HA}} \beta \mathrm{Th}^{4+}$ value of 23 was used to calculate the speciation.

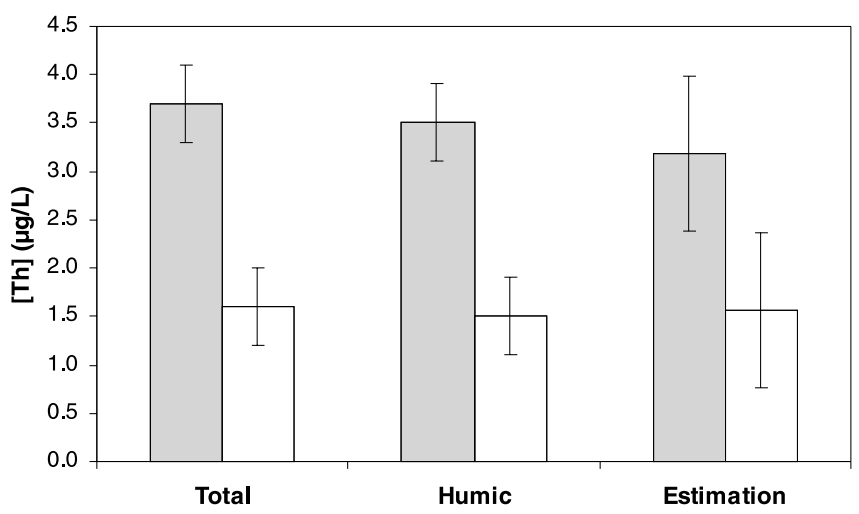

Fig. 10. Experimental [ 92 Table 1, 93 Table 2] and calculated distribution of Th(IV) bound to HA in GoHy-573 (shaded columns) and GoHy-2227 (empty columns) groundwaters; using $\log _{\mathrm{BM}}^{\mathrm{HA}} \beta\left(\mathrm{Th}^{4+}\right)=$ 21.3. 
With these assumptions, the Th(IV) percent bound to HA is always under $5 \%$ showing a weak influence of organic matter on the speciation of Th(IV). This result is in agreement with the experimental results in [103].

The results obtained using the values determined here, demonstrate that thorium is predominantly bound to $\mathrm{HA}$ when the concentration of humic sites $[\equiv \mathrm{HA}]$ is larger than $2 \times 10^{-5} \mathrm{eq} / \mathrm{L}$ (corresponding roughly to $5 \times 10^{-3} \mathrm{~g} / \mathrm{L}$ ) for $\mathrm{pH} \leq 8$, and the Th(IV)-HA complexes percent is still above $10 \%$ at $2 \times 10^{-6} \mathrm{eq} / \mathrm{L}$ (corresponding roughly to $5 \times 10^{-4} \mathrm{~g} / \mathrm{L}$ ). Such concentrations may be encountered in natural waters, even in sedimentary conditions [94].

Hence the complexation of Th(IV) (considered as an analogue of tetravalent actinides) by HA, should not be neglected $a$ priori in speciation calculations, in particular for applications in natural water conditions.

\section{Conclusions}

The technique we have used to investigate the complexation of $\mathrm{Th}(\mathrm{IV})$ by humic substances (in particular, HA) is based on the study of a ternary system involving the cation, HA and a mineral surface (silica colloids) considered as a competitor for HA.

In the case of the binary system Th(IV)-silica, the surface complexation constants obtained allowed to quantify the sorption of Th(IV) onto amorphous silica using SCM without electrostatic term and taking into account the different hydroxo complexes of thorium.

HA have an important effect upon the sorption of tetravalent actinides onto silanol surface groups of silica, even in the $\mathrm{pH}$ range of groundwater $(\mathrm{pH} \geq 6)$. A strong decrease of $\mathrm{Th}(\mathrm{IV})$ sorption onto silica is observed due to the formation of humate complexes in solution. Using the ternary system (silica, Th(IV), HA), a quantification of the complexation of $\mathrm{Th}(\mathrm{IV})$ by HA has been performed in a $\mathrm{pH}$ range relevant of natural media, allowing the determination of global interaction constants $\left({ }^{\mathrm{HA}} \beta\right)$ for the system $\mathrm{Th}(\mathrm{IV})-\mathrm{HA}$. These values are dependent of the Th hydrolysis constant data sets, and are higher than other reported values in the literature. The possible formation of mixed complexes (hydro-humate complexes) or the implication of different complexing sites may explain these high interaction constants obtained in the neutral-basic $\mathrm{pH}$ range. Further studies are in progress to determine more precisely the nature of the complexes formed. The proposed global interaction constants also allow representation or comparison of independent experimental data obtained by other authors.

Moreover, this study allows exploring the potentially strong influence of HA in natural systems onto the chemistry of tetravalent elements in general, and of tetravalent actinides in particular at the laboratory scale. In the case of Th(IV), cation binding is apparently important even at relatively low HA concentration $\left(10^{-3} \mathrm{~g} / \mathrm{L}\right)$ in the neutral to slightly alkaline $\mathrm{pH}$ range. This is indicative of the importance of humic complexation reactions in a large variety of natural waters.

Acknowledgment. The authors would like to thank anonymous referees and Professor Charles Madic for their contributions. The present work received a financial support from the Commission of the European
Communities through the European Community "HUMICS project" (FI4W-CT96-0027). Part of the material in this paper was presented as a poster at the Migration 2001 Conference in Bregenz, Austria, September 16-21, 2001.

\section{References}

1. Buddmeier, R., Hunt, J.: Transport of colloidal contaminants in groundwater: radionuclide migration at the Nevada test site. Appl. Geochem. 3, 535 (1988).

2. McCarthy, J. F., Sanford, W. E., Stafford, P. L.: Lanthanide field tracers demonstrate enhanced transport of transuranic radionuclides by natural organic matter. Environ. Sci. Technol. 32, 3901 (1998).

3. Fujikawa, Y., Zheng, J., Cayer, I., Sugahara, M., Takigami, H., Kudo, A.: Strong association of fallout plutonium with humic and fulvic acid as compared to uranium and ${ }^{137} \mathrm{Cs}$ in Nishiyama soils from Nagasaki, Japan. J. Radioanal. Nucl. Chem. 240, 69 (1999).

4. Kersting, A. B., Efurd, D. W., Finnegan, D. L., Rokop, D. J., Smith, D. K., Thompson, J. L.: Migration of plutonium in groundwater at the Nevada Test Site. Nature 397, 56 (1999).

5. Minai, Y., Choppin, G., Sisson, D. H.: Humic material in well water from the Nevada test Site. Radiochim. Acta 56, 195 (1992).

6. Moulin, V., Ouzounian, G.: Role of colloids and humic substances in the transport of radioelements through the geosphere. Appl. Geochem. Suppl. Issue 1, 179 (1992).

7. Petterson, C., Ephraim, J., Allard, B.: On the composition and properties of humic substances isolated from deep groundwater and surface waters. Org. Geochem. 21, 443 (1994).

8. Ryan, J. L., Rai, D.: Thorium(IV) hydrous oxide solubility. Inorg. Chem. 26, 4140 (1987).

9. Adair, J. H., Krarup, H. G., Venigalla, S., Tsukada, T.: A review of the aqueous chemistry of the zirconium-water system to $200^{\circ} \mathrm{C}$. Mat. Res. Soc. Symp. Proc. 432, 101 (1997).

10. Östhols, E.: Thorium sorption on amorphous silica. Geochim. Cosmochim. Acta 59, 1249 (1995).

11. Nash, K. L., Fried, S., Friedman, A. M., Sullivan, J. C.: Redox behavior, complexing, and adsorption of hexavalent actinides by humic acid and selected clays. Stiring marine disposal of highlevel radioactive waste. Environ. Sci. Technol. 15, 834 (1981).

12. Marquardt, C., Herrman, G., Trautmann, N.: Complexation of neptunium $(\mathrm{V})$ with humic acids at very low concentrations. Radiochim. Acta 73, 119 (1996).

13. Pirlet, V., van Iseghem, P., Dierckx, A., Desreux, J.-F.: The investigation of the neptunium complexes formed upon interaction of high level waste glass and Boom Clay media. J. Alloys Comp. 271, 267 (1998).

14. Zeh, P., Kim, J. I., Marquardt, C. M., Artinger, R.: The reduction of $\mathrm{Np}(\mathrm{V})$ in groundwater rich in humic substances. Radiochim. Acta 87, 23 (1999).

15. André, C., Choppin, G. R.: Reduction of $\mathrm{Pu}(\mathrm{V})$ by humic acid. Radiochim. Acta 88, 613 (2000).

16. Choppin, G. R.: Utility of oxidation state analogs in the study of plutonium behavior. Radiochim. Acta 85, 89 (1999).

17. Kautsky, H., Weißlau, H.: Darstellung von Ionenaustauschern durch Oberflächenumladungen Au Silicagel. Z. Naturforschg. 9B, 569 (1954).

18. James, R. O., Healy, T. W.: Adsorption of hydrolysable metal ions at the oxide water interface. II. Charge reversal of $\mathrm{SiO}_{2}$ and $\mathrm{TiO}_{2}$ colloids by adsorbed $\mathrm{Co}(\mathrm{II}), \mathrm{La}(\mathrm{III})$, and $\mathrm{Th}(\mathrm{IV})$ as model systems. J. Colloid Interface Sci. 40, 53 (1972).

19. Laflamme, B. D., Murray, J. W.: Solid/solution interaction: the effect of carbonate alkalinity on adsorbed thorium. Geochim. Cosmochim. Acta 51, 243 (1987).

20. Hunter, K. A., Hawke, D. J., Kwee Choo, L.: Equilibrium adsorption of thorium by metal oxides in marine electrolytes. Geochim. Cosmochim. Acta 52, 627 (1987).

21. Righetto, L., Bidoglio, G., Marcandalli, B., Bellobono, I. R.: Surface interactions of actinides with alumina colloids. Radiochim. Acta 44/45, 73 (1988).

22. Jakobsson, A.- M., Albinsson, Y., Rundberg, R. R.: Studies of surface complexation of $\mathrm{H}^{+}, \mathrm{NpO}_{2}{ }^{+}, \mathrm{Co}^{2+}, \mathrm{Th}^{4+}$ onto $\mathrm{TiO}_{2}$ and $\mathrm{H}^{+}$, $\mathrm{UO}^{2+}$ onto alumina. Svensk Kärnbränslehantering $\mathrm{AB}$ (SKB), Report TR 98-15 (1998). 
23. Cromières, L., Moulin, V., Fourest, B., Guillaumont, R., Giffaut, E.: Sorption of thorium onto hematite colloids. Radiochim. Acta 82, 249 (1998).

24. Dzomback, D. A., Morel, M. M.: Surface complexation modelling. John Wiley \& Sons, New-York (1990).

25. Zaki, M. R., Kolta, K. B.: On the sorption of thorium ions from aqueous nitrate solutions by silica gel. Indian J. Chem. 19A, 630 (1980).

26. Rydberg, J., Rydberg, B.: Adsorption on glass and polythene from solution of thorium and thorium complexes in tracer concentration. Sv. Kem. Tidskr. 64, 200 (1952).

27. Lieser, K., H., Hill, R.: Chemistry of thorium in the hydrosphere and in the geosphere. Radiochim. Acta 56, 141 (1992).

28. Lieser, K., H., Hill, R.: Hydrolysis and colloid formation of Th in water and consequences for its migration behaviour - comparison with uranium. Radiochim. Acta 56, 37 (1992).

29. Michard, G., Alaux-Negrel, G., Toulhoat, P., Beaucaire, C., Ouzounian, G.: Major and trace element regulation in natural granitic waters. Application to deep radioactive waste disposal. HLRW Management Proceedings, Las Vegas (1991) p. 179.

30. Zeh, P., Kim, J. I., Buckau, G.: Aquatic colloids composed of humic substances, Binding models concerning natural organics in performance assessment. OECD NEA Proceedings (1995) p. 81.

31. Miekeley, N., Vale, M. G. R., Tavares, T. M., Lei, W.: Some aspects of the influence of surface and ground water chemistry on the mobility of thorium in the "Morro do Ferro"-environment. Mat. Res. Soc. Symp. Proc. 11, 725 (1982).

32. Miekeley, N., Dotto, R. M., Kuchler, I. L., Insalta, P.: The importance of organic compounds on the mobilization and bioassimilation of thorium in the Morro do Ferro environment. Mat. Res. Soc. Symp. Proc. 44, 591 (1985).

33. Nordén, M., Albinsson, Y., Ephraim, J. H., Allard, B.: A comparative study of europium, thorium and uranium binding to an aquatic fulvic acid. Mat. Res. Soc. Symp. Proc. 294, 759 (1993).

34. Niven, S. E. H., Moore, R. M.: Effect of natural colloidal matter on the equilibrium adsorption of thorium in seawater. In: $R a$ dionuclides: A tool for Oceanography. (Guary, J. C. ed.) Elsevier, Amsterdam (1988) p. 111.

35. Nash, K. L., Choppin, G. R.: Interaction of humic and fulvic acids with Th(IV). J. Inorg. Nucl. Chem. 42, 1045 (1980).

36. Choppin, G. R., Allard, B.: Complexes of actinides with naturally occurring organic compounds. In: Handbook on the Physics and Chemistry of the Actinides. (Freeman, A. J., Keller, C. eds.) Elsevier, Amsterdam (1985) p. 407.

37. Torres, R. A.: Humic acid complexation of europium, americium and plutonium. PhD Thesis, Florida State University, (1982).

38. Torres, R., A., Choppin, G., R.,: Europium(III) and Americium(III) stability constants with humic acid. Radiochim. Acta 35, 143 (1984).

39. Baes, C. F., Mesmer, R. E.: The hydrolysis of cations. Wiley Interscience Publication, New-York (1976).

40. Portanova, R., di Bernardo, P., Traverso, O., Mazzochin, A., Magon, L.: Thermodynamic properties of actinide complexes. 2 . Thorium(IV)-acetate system. J. Inorg. Nucl. Chem. 37, 2177 (1975).

41. Murphy, R. J., Lenhart, J. J., Honeyman, B. D.: The sorption of thorium(IV) and uranium(VI) to hematite in the presence of natural organic matter. Colloids Surf. A 157, 47 (1999).

42. Grenthe, I., Lagerman, B.: Studies on metal carbonate equilibria. 23. Complex formation in the $\mathrm{Th}(\mathrm{IV})-\mathrm{H}_{2} \mathrm{O}-\mathrm{CO}_{2}(\mathrm{~g})$ system. Acta Chim. Scand. 45, 231 (1991).

43. Östhols, E., Bruno, J., Grenthe, I.: On the influence on mineral dissolution: III. The solubility of microcrystalline $\mathrm{ThO}_{2}$ in $\mathrm{CO}_{2}-\mathrm{H}_{2} \mathrm{O}$ media. Geochim. Cosmochim. Acta 58, 613 (1994).

44. Zuyi, T., Huanxin, G.: Use of the ion exchange method for the determination of stability constants of thorium with humic and fulvic acids. Radiochim. Acta 65, 121 (1994).

45. Davis, J. R., Higgo, J. J. W., Noy, D. J., Hooker, P. J.: Complexation studies of uranium and thorium with a natural fulvic acid. INE, Report FZKA 6524, Karlsruhe (2000).

46. Denecke, M. A., Bublitz, D., Kim, J. I., Moll, H., Farkes, I.: EXAFS investigation of the interaction of hafnium and thorium with humic acid and Bio-Rex70. J. Synchr. Rad. 6, 394 (1999).

47. Schild, D., Marquardt, C. M.: Analysis of Th(IV)-humate by XPS. Radiochim. Acta 88, 587 (2000).
48. Dierckx, A., Maes, A., Vancluysen, J.: Mixed complex formation of $\mathrm{Eu}^{3+}$ with humic acid and a competing ligand. Radiochim. Acta 66/67, 149 (1994).

49. Glaus, M. A., Hummel, W., van Loon, L. R.: Stability of mixedligand complexes of metal ions with humic substances and low molecular weight ligands. Environ. Sci. Technol. 29, 2150 (1995).

50. Kinniburgh, D. G., Milne, C. J., Benedetti, M. F., Pinheiro, J. P., Filius, J., Koopal, L. K., van Riemsdijk, W. H.: Metal ion binding by humic acid: application of the NICA-Donnan model. Environ. Sci. Technol. 30, 1687 (1996).

51. Davis, J. A.: Complexation of trace metals by adsorbed natural organic matter. Geochim. Cosmochim. Acta 48, 679 (1984).

52. Righetto, L., Bidoglio, G., Azimonti, G., Bellobono, I. R.: Competitive actinide interactions in colloidal humic acid-mineral oxide systems. Environ. Sci. Technol. 25, 1913 (1991).

53. Zachara, J. M., Resch, C. T., Smith, S. C.: Influence of humic substances on $\mathrm{Co}^{2+}$ sorption by a subsurface mineral separate and its mineralogic components. Geochim. Cosmochim. Acta 58, 553 (1994).

54. Labonne-Wall, N., Moulin, V., Villarem, J.-P.: Retention properties of humic substances onto amorphous silica: consequences for the sorption of cations. Radiochim. Acta 79, 37 (1997).

55. Takahashi, Y., Minai, Y., Ambe, S., Makide, Y., Ambe, F.: Comparison of adsorption behavior of multiple inorganic ions on kaolinite and silica in the presence of humic acid using the multitracer technique - a comparison with dissolved aluminum. Geochim. Cosmochim. Acta 63, 815 (1999).

56. Reiller, P., Moulin, V., Casanova, F., Dautel, C.: Retention behaviour of humic substances onto mineral surfaces and consequences upon thorium (IV) mobility: case of iron oxides. Appl. Geochem. 17, 1551 (2002).

57. van de Weerd, H., van Riemsdijk, W. H., Leijnse, A.: Modelling the dynamic adsorption/desorption of NOM mixture: Effects of physical and chemical heterogeneity. Environ. Sci. Technol. 33, 1675 (1999).

58. Zhou, Q., Maurice, P. A., Cabaniss, S.: Size fractionation upon adsorption of fulvic acid on goethite: equilibrium and kinetic study. Geochim. Cosmochim. Acta 65, 803 (2001).

59. Vuceta, J., Morgan, J.: Chemical modeling of trace metals in fresh waters: role of complexation and adsorption. Environ. Sci. Technol. 12, 1302 (1978).

60. Degueldre, C.: Colloid properties in groundwaters from crystalline formations. NAGRA, Report NTB 92-05 (1992).

61. Gardiner, M. P., Grindrod, P., Moulin, V.: The role of colloids in the transport of radionuclides from a radioactive waste repository: implication on safety assessment. CCE, Report EUR 19781 EN, Bruxelles (2001).

62. Brady, P. V.: Silica surface chemistry at elevated temperatures. Geochim. Cosmochim. Acta 56, 2941 (1992).

63. Lyklema, J.: Fundamentals of colloid and interface science, Volume I: Fundamentals. Academic Press, London (1995).

64. Kim, J. I., Buckau, G., Klenze, R., Rhee, D. S., Wimmer, H.: Characterisation and complexation of humic acids. CCE, Report EUR 13181, Brussels (1991).

65. Vekshin, N. L.: Screening hypochromism of chromophores in macromolecular biostructures. Biophysics 44, 41 (1999).

66. Ekberg, C., Albinsson, Y., Comarmond, M. J., Brown, P. L.: Studies on the complexation behavior of thorium(IV). 1. Hydrolysis equilibria. J. Solut. Chem. 29, 63 (2000).

67. Grenthe, I., Fuger, L., Konings, R. G. M., Lemire, R. J., Muller, A. B., Nguyen-Trung, C., Wanner, H.: Chemical Thermodynamics of Uranium. North Holland, Amsterdam (1992).

68. Labonne, N.: Rôle des matières organiques dans les phénomènes de rétention des actinides sur la silice. $\mathrm{N}^{\circ} 4601,13$ décembre 1993, Thèse de l'Université Paris XI Orsay, Paris-Orsay (1993).

69. Cromières, L.: Sorption d'éléments lourds (U(VI), Np(V), Th(IV), Am(III), Co(II), Cs(I), I(-I)) sur des colloïdes d'hématite. Thèse de l'Université Paris XI, Orsay (1996).

70. João, A., Bigot, S., Fromage, F.: Étude des carbonates complexes des éléments IVB I - Détermination de la constante de stabilité du pentacarbonatothorate (IV). Bull. Soc. Chim. France 42 (1987).

71. Rai, D., Felmy, A. R., Moore, D. A., Mason, M. J.: The solubility of Th(IV) and U(IV) hydrous oxides in concentrated $\mathrm{NaHCO}_{3}$ and $\mathrm{Na}_{2} \mathrm{CO}_{3}$ solutions. Mat. Res. Soc. Symp. Proc. 353, 1143 (1995). 
72. Felmy, A. R., Rai, D., Sterner, S. M., Mason, M. J., Hess, N. J., Conradson, S. D.: Thermodynamic models for highly charged aqueous species: Solubility of Th(IV) hydrous oxide in concentrated $\mathrm{NaHCO}_{3}$ and $\mathrm{Na}_{2} \mathrm{CO}_{3}$ solutions. J. Solut. Chem. 26, 233 (1997).

73. Pazukhin, M., Krivokhatskiy, A. S., Kudryavtsev, E.: Possible formation of plutonium(IV) complexes with soluble silicon-oxygen compounds. Soviet Radiochem. 32, 325 (1990).

74. Herbellin, A. L., Westall, J. C.: FITEQL A computer program for determination of chemical equilibrium constants from experimental data. Department of Chemistry, Oregon State University, Report 96-01 (1996).

75. Davis, J. A.: Adsorption of natural dissolved organic matter at the oxide/water interface. Geochim. Cosmochim. Acta 46, 2381 (1982).

76. Schulthess, C. P., Huang, C. P.: Humic and fulvic acid adsorption by silicon and aluminum oxide surfaces on clay minerals. Soil Sci. Soc. Am. J. 55, 34 (1991).

77. Drever, J. I., Stillings, L. L.: The role of organic acids in mineral weathering. Colloids Surf. A 120, 167 (1997).

78. Schubert, J.: J. Phys. Coll. Chem. 52, 340 (1948).

79. Meyer, M. L., Bloom, P. R.: Boric and silicic acid adsorption and desorption by a humic acid. J. Environ. Qual. 26, 63 (1997)

80. Pokrovski, G. S., Schott, J.: Experimental study of the complexation of silicon and germanium with aqueous organic species: implication for germanium and silicon transport and $\mathrm{Ge} / \mathrm{Si}$ ratio in natural waters. Geochim. Cosmochim. Acta 62, 3413 (1998).

81. Östhols, E., Manceau, A., Farges, F., Charlet, L.: Adsorption of thorium on amorphous silica: An EXAFS study. J. Colloid Interface Sci. 194, 10 (1997).

82. Schindler, P. W., Stumm, W.: In Aquatic Surface Chemistry. (Stumm, W. ed.) Wiley-Interscience, New York (1987) p. 83.

83. Geckeis, H., Klenze, R., Kim, J. I.: Solid-water interface reactions of actinides and homologues: sorption onto mineral surfaces. Radiochim. Acta 87, 13 (1999).

84. del Nero, M., Mad , B., Bontems, G., Clément, A.: Adsorption of neptunium(V) on hydrargilite. Radiochim. Acta 76, 219 (1997).

85. Davis, J. A., Kent, D. B.: Surface complexation modeling in aqueous geochemistry. In: Reviews in Mineralogy, Mineral-Water Interface Geochemistry. (Hochella, M. F., White, A. F. eds.) Mineralogy Society of America, Washington (1990) p. 225.

86. Schindler, P. W.: Co-adsorption of metal ions and organic ligand: formation of ternary surface complexes. In: Reviews in Mineralogy, Mineral-Water Interface Geochemistry. (Hochella, M. F., White, A. F. eds.) Mineralogy Society of America, Washington (1990) p. 291

87. Yates, D. E., Healy, T. W.: The structure of the silica/electrolyte interface. J. Colloid Interface Sci. 55, 9 (1976).

88. Wells, J. D., Koopal, L. K., de Keizer, A.: Monodisperso, nonporous, spherical silica particles. Colloids Surf. A 166, 171 (2000).
89. Neck, V., Kim, J. I.: Solubility and hydrolysis of tetravalent actinides. Radiochim. Acta 89, 1 (2001).

90. Moulin, C., Amekraz, B., Hubert, S., Moulin, V.: Study of thorium hydrolysis species by electrospray-ionization mass spectrometry. Anal. Chim. Acta 441, 269 (2001).

91. Hummel, W., Glaus, M. A., Van Loon, L. R.: Trace metal-humate interaction. II. The conservative roof model and its application. Appl. Geochem. 15, 975 (2000).

92. Kim, J. I., Rhee, D. S., Buckau, G., Morgenstern, A.: Americium(III)-humate interaction in natural groundwater: Influence of purification on complexation properties. Radiochim. Acta 79, 173 (1997).

93. Kim, J. I., Marquardt, C. M.: Chemical reaction of $\mathrm{Np}(\mathrm{V})$ with humic colloids in groundwater: Influence of purification on the complexation behaviour. Radiochim. Acta 87, 105 (1999).

94. Reiller, P., Moulin, V., Giffaut, E.: On the influence of humic substances upon radionuclide speciation: A sensitivity study. Appl. Geochem. (submitted).

95. Moulin, V., Moulin, C.: Radionuclide speciation in the environment: a review. Radiochim. Acta 89, 773 (2001).

96. Panak, P., Klenze, R., Kim, J. I.: A study of ternary complexes of $\mathrm{Cm}$ (III) with humic acid and hydroxyde or carbonate in neutral $\mathrm{pH}$ range by time resolved laser fluorescence spectroscopy Radiochim. Acta 74, 141 (1996).

97. Morgenstern, M., Klenze, R., Kim, J. I.: The formation of mixedhydroxo complexes of $\mathrm{Cm}$ (III) and Am(III) with humic acid in the neutral $\mathrm{pH}$ range. Radiochim. Acta 88, 7 (2000).

98. Kinniburgh, D. G., van Riemsdijk, W. H., Koopal, L. K., Borkovec, M., Benedetti, M. F., Avena, M. J.: Ion binding to natural organic matter: competition, heterogeneity, stoichiometry and thermodynamic consistency. Colloids Surf. A 151, 147 (1999).

99. Hummel, W., Glaus, M., A., Van Loon, L. R.: Complexation of radionuclides with humic substances: the metal concentration effect. Radiochim. Acta 84, 111 (1999).

100. Glaus, M. A., Hummel, W., Van Loon, L. R.: Trace metal-humate interactions. I. Experimental determination of conditional stability constants. Appl. Geochem. 15, 953 (2000).

101. Parkhurst, D. L.: PhreeqC. A computer program for speciation, batch-reaction, one-dimensional transport, and inverse geochemical calculations. U.S. Geological Survey, Water-Resources Investigations, Report 95-4227, Lakewood, Colorado, USA (1996).

102. Zeh, P., Czerwinski, K. R., Kim, J. I.: Speciation of uranium in Gorleben groundwaters. Radiochim. Acta 76, 37 (1997).

103. Glaus, M. A., Baeyens, B., Lauber, M., Rabung, T., van Loon, L. R.: Water-extractable organic matter from opalinus clay: effect on sorption and speciation of $\mathrm{Ni}(\mathrm{II}), \mathrm{Eu}(\mathrm{III})$ and $\mathrm{Th}(\mathrm{IV})$. Paul Scherrer Institut, Report 01-14, Villigen (2001).

104. Czerwinski, K. R., Kim, J. I., Rhee, D. S., Buckau, G.: Complexation of trivalent actinides ions $\left(\mathrm{Am}^{3+}, \mathrm{Cm}^{3+}\right)$ with humic acids: the effect of ionic strength. Radiochim. Acta 72, 179 (1996). 